\title{
Trophic Relations of Roe Deer in a Fresh Deciduous Forest
}

\author{
Simona KOSSAK
}

Kossak S., 1983: Trophic relations of roe deer in a fresh deciduous forest. Acta theriol, 28, 6:83-127 [With 8 Tables \& 5 Figs.]

Examination was made of the trophic relations of the roe deer Capreolus capreolus (Linnaeus, 1758) in three age classes of tree stand and also in the partly-wooded fallow land of a fresh deciduous forest in the Bialowieza Primeval Forest. Data were obtained by means of direct observations of contacts by groups of tame roe deer with plants. Food supply and demand relations were investigated by means of comparing intensity of feeding by these animals on different plant species with the abundance of the latter's occurrence in the area. Roe deer consumed 97 out of the 155 ligneous and herb plant species growing there. This moderate consumption of the food supply (about $63 \%$ ) was due to the low degree of occurrence of a considerable number of species. Inclusion of a plant in the roe deer's diet and its significant contribution towards the composition of the animals' diet depend chiefly on the degree of the plant's occurrence in the area. A characteristic feature of the food habits of roe deer in a fresh deciduous forest is that demand is defined by supply. From about $72 \%$ to $88 \%$ of contacts with plant species consumed in proportion to their occurrence were recorded in successive age classes of tree stands. Spectes in respect of which demand exceeds supply form from $1.8 \%$ to $4.2 \%$ of contacts. Using what are termed "bits", i.e. standardised units of consumption, examination was made of the yearly cycle of the roe deer's consumption. Plants which are not becoming ligneous, i.e. herb plants and the current year's growth of iigneous plants, and their leaves, form food particularly attractive to roe deer. The considerable proportion of browse in the animals' diet in winter is to a great extent due to the lack of more suitable food, as is shown by the abrupt decrease in their consumption of browse in favour of herb layer plants when winter thaws expose the herb layer. Roe deer have been shown to prefer the generative parts of herb layer plants. 'To conclude the discussion on the roe deer's food preferences it was found that the picture of the trophic relations of roe deer is the resultant, maintained in dynamic equilibrium of the abiotic and biotic elements, variable in time and space, of the animals' requirements. The sole function of food preference is to maintain this dynamic balance. The decisive factor in formation of food relations is always the food supply currently available.

[Forest Res. Inst., Sect. Nat. Protection, 17-230 Bialowieża, Poland]

1. Introduction

2. Material and methods

3. Supply and demand for plants

3.1. Description of the feeding habits of roe deer. ${ }^{*} \cdot{ }^{\prime} \cdot{ }^{\prime} \cdot{ }^{\prime} \cdot{ }^{\prime}$

3.2. Qualitative and quantitative consumption of food resources by roe deer

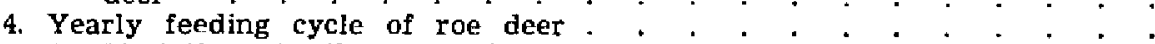

4.1. Variations in the proportion of groups of plants in the roe deer's diet over the yearly cycle. 
4.2. Variations in the numbers of ligneous and herb plant species in the roe deer's diet over the yearly cycle . + . . 100

4.3. Composition of the roe deer's diet over the yearly cycle . . . . 102

5. Discussion species herbs, grasses and sedges, and on fungi . . . . . . 106

\section{INTRODUCTION}

The roe deer, Capreolus capreolus (Linnaeus, 1758), is a characteristic representative of the primitive, concentrating-selective, type of food habits (Hofmann, 1978, 1979; Van de Veen, 1979). It possesses a simple stomach of relatively small capacity, in which food remains for an relatively short time, and consequently the animal must consume food during numerous short feeding periods (8-11 times per 24 hours) (Bubenik 1959 ; Kurt, 1968). This type of stomach is not adapted to utilizing poor food, from large quantities of which it would be possible to extract only a small amount of nutritive substances, but has the ability to select easily digested high-energy food (Ellenberg, 1975 ; Hofmann, 1978, 1979). The composition of microorganisms present in the roe deer's alimentary tract also deserves attention. Only one species of infusorian (Entodinium dubardii Buiss.) lives in the roe deer's stomach, which is exceptional in comparison with other species of deer (Drescher-Kaden \& Seifelnasr, 1977). E. dubardii is presumably very sensitive both to any change in the composition of food and to monotonous food (Bubenik, 1959 ; Bruchholz, 1975).

All the foregoing results in the roe deer being the most fastidious species of all the deer kind in respect of its food requirements. On the other hand, it is known that it is the most common representative of deer in extensive areas of Eurasia. It can live equally well in a dry and cold climate or a humid and warm one, in a forest or field habitat. It arises from this that while retaining all its "fastidiousness" in choice of food, the roe deer must be able to make up its diet from the food supply currently available in the given area.

That this is in fact the case is shown by the discrepancies between results of studies on the consumption of the roe deer's food obtained in different parts of its range. Even the food from one geographical region, but from different natural biotopes, may exhibit far-reaching differences, hence the main emphasis in studies on its food should be given to ascertaining the mechanisms forming the picture of trophic relations.

The purpose of the studies undertaken was to examine the trophic relations of the roe deer in a mixed forest, paying particular attention 
to supply and demand relations and seasonal variations in the composition of the food consumed by this species. The studies discussed in the further part of this paper were carried out in the Bialowieza Primeval Forest, since despite the pressure exerted by man over the course of many centuries, this forest region has retained a relatively natural character and considerable variety of flora (Falinski, 1968), which facilitates revelation of the roe deer's natural food preferences. The results obtained under these conditions may be useful for interpreting the picture of food relations in the case of animals subject to pressure by humans in the wide sense of the word.

\section{MATERIAL AND METHODS}

Studies on the trophic relations of roe deer in a meso-eutrophic fresh deciduous forest Melitti-Carpinetum Sok. 1976 were carried out from June 1976 to April 1979. Observations were made of a total number of 7 roe deer (3 females and 4 males) obtained from the wild state at the age of 1 to 7 days and artificially fed (Kossak, 1981). After the period of rearing the young animals had ended, they were suppplied with supplementary food, i,e. the fodder used in open hunting ranges solely during the time the area was under snow. Over the whole year the animals were kept supplied with salt in salt-licks and drinking facilities were made available to them in summer.

During the first 6 months of life the roe deer lived in an 0.84 ha enclosure situated in a fresh deciduous forest. The enclosure included fallow land partly covered by a young selfsown tree stand, and in the further part of this paper has been referred to as the fallow land. As from the 7th month of life the roe deer were placed in an enclosure fencing-in 21.34 ha of fresh mixed deciduous forest. The proportion of age classes of the total area was as follows: 3.14 ha of plantation set up in $1976,10.10$ ha of young trees from 12 to 22 years old (thicket) and $8.10 \mathrm{ha}$ of timber stand, from 118 to 158 years old.

The whole of the material on the roe deer's food relations was collected by means of direct observations, the observer moving as the individual observed moved, and recording on a tape recorder data on the food consumed and all data on the animals' behaviour and external factors capable of affecting the animals' bchaviour. One observation period lasted, in the case of fawns, for their whole activity period (from rest to rest) and for adult animals approximately one hour, with a grand total of 286 observation periods. Observations were made at different times of the day, morning hours predominating, in accordance with the animals' activity in the given season. Data on annual and 24-hour cycles of their activity has been discussed separately (Kossak \& Mystiniski, in prep.).

One observation period took a day, endeavour being made to observe a different individual each time. Observations began with searching for the roe deer in the enclosure, avoiding any attempts at attracting them in order to avoid disturbance in their choice of a feeding place. If the individual concerned was not feeding, the observer either waited until the end of the rest period, or chose for observation an individual active during the period.

In order to define the composition of the roe deer's food the method of 
recording contacts was used, considering as one contact a single cropping and swallowing of a piece, the whole or several plants of the given species. The following description was adhered to in recording contacts : leaf, shoot with leaves or without leaves, cropped from growing plants, leaves or shoots lying on the ground, the barren part of a herb plant, flowers, fruits and seeds cropped from plants growing or fallen on to the ground. In some cases definition was limited to genus only, e.g. Viola sp. Grasses and sedges were considered jointly as one food group, and the same was done in relation to fungi and mushrooms.

As feeding units recorded by the contact system differed greatly from each other in respect of mass,in order to define the percentage of different plants in the roe deer's diet over the yearly eycle an attempt was made at partial unification of data by means of a thass conversion factor. This was obtained by the following method: the observer recorded on a tape recorder the contacts consumed by a given animal, and at the same time took samples similar in size and appearance from the same species and, wherever possible, a sample of the plant itself. Samples were taken on rainless days after dew had dried, placed in a plastic container

\section{Table 1}

Mass conversion factors used for unification of contacts.

During winter period with a snow cover (Dec. 1 - April 10) no conversion factors were used because of lack of undergrowth.

\begin{tabular}{|c|c|c|c|c|c|c|c|c|}
\hline \multirow[t]{2}{*}{ Date } & \multicolumn{4}{|c|}{ Average mass of 1 contact in $g$} & \multicolumn{4}{|c|}{ Conversion factor } \\
\hline & $\begin{array}{l}\text { Herb } \\
\text { plants }\end{array}$ & $\begin{array}{l}\text { Ligneous } \\
\text { plants }\end{array}$ & Fungi & Acorns & $\begin{array}{l}\overline{\text { Her }} \\
\text { plants }\end{array}$ & $\begin{array}{l}\text { Ligneous } \\
\text { plants }\end{array}$ & Fungi & Acorns \\
\hline $10.4-25.5$ & 0.38 & 0.23 & & & 1 & 0.6 & & \\
\hline $26.5-30.6$ & 0.45 & 0.36 & & & 1 & 0.8 & & \\
\hline $1.7-31.7$ & 0.27 & 0.37 & & & 1 & 1.4 & & \\
\hline $1.8-31.8$ & 0.19 & 0.30 & & & 1 & 1.6 & & \\
\hline $1.9-30.9$ & 0.20 & 0.40 & 1.26 & $2.00^{3}$ & 1 & 2.0 & 6.3 & 10.0 \\
\hline $1.10-30.11$ & 0.20 & 0.42 & & & 1 & 2.0 & & \\
\hline Winter & & & & & & & & \\
\hline $\begin{array}{l}\text { thaw ; snow } \\
\text { absent }\end{array}$ & 0.18 & 0.42 & & & 1 & 2.0 & & \\
\hline
\end{tabular}

1 Weight of one acorn is given in accordance with "Zasady hodowlane" [Breeding Principles] (1969).

and immediately on completion of observations were weighed and divided into ligneous and herb plants and fungi. The fresh mass of the sample was next divided by the recorred number of contacts, obtaining the average weight of a contact in the given group of plants. This weight was the resultant of different sized parts and species of plants allocated to one group. A total of 19,682 sample contacts were taken, and mass conversion factors calculated on this basis (Table 1). After standardisation the contacts were termed "bits".

In order to check whether roe deer prefer plants in the flowering phase, a test was used for frequency of occurrence of flowering plants in the area and in the animals' food, taking Anemone nemorosa and Oxalis acetosella for analysis on account of the considerable proportion they form of the roe deer's food, their abundant flowering and the easy counting of flowers and leaves cropped by these animals. The ration of flowering plants to infertile plants in the animals' diet was defined by means of direct observations as described above, while the above ration of the plants occurring in the area was defined by means of counting 
all plants in the generative and vegetative phase in $50 \times 50 \mathrm{~cm}$ areas marked out at random. In the case of Anemone nemorosa 130 areas were selected at random in the old tree stand, the young tree stand and in the plantation, and for Oxalis acetosella by random selection of 40 areas in the old tree stand. Samples were taken during the flowering apogeum of both species (May 3rd and 4th 1977).

In order to define the abundance of the different species of plants, a series of 42 phytosociological lists was drawn up and on this basis (using the BraunBlanquet scale) calculation was made of the percentage of different species in successive age classes of tree stand. The data were referred to the Braun-Blanquet model (Pawlowski, 1972), giving the value of the coefficient of abundance $D$ (Deckungswert) :

$$
D=-\frac{\text { total of average percentages of cover in all lists }}{\text { number of lists }} \times 100
$$

All data on the roe deer's food were considered jointly in relation to observations of different individuals and years, treating the material as relating to roe deer. By the term "roe deer" is meant the resultant of the activity of animals of both sexes and different ages present in the study area.

\section{SUPPLY AND DEMAND FOR PLANTS}

On the basis of the whole of the material collected, consisting of 121,706 recorded contacts of the roe deer with plants, a floristic list was drawn up illustrating supply and demand for plants under the conditions prevailing in a mixed deciduous forest (Table 2). All the plant species occurring in the study area were taken into consideration, giving the age class of the tree stand and number of contacts recorded. Species in the table were arranged in order of decreasing total number of contacts. The value of the coefficient of abundance $D$ was placed by each of the species. When the species occurred in the shrub (b) or herb layer (c) both values were given.

Definition of the degree to which roe deer make use of the food available to them was based on value $D$ for different plants and on the percentage of plants in the total number of contacts recorded in successive age classes for the tree stand and fallow land. Table 3 gives the key used for defining the numbers of the plant species in the area and its percentage in the roe deer's food. Both these values were compared for each species and the following categories of plants were established:

(A) Species consumed in proportion to their occurrence:

(1) occurring numerously - with considerable proportion in contacts

(2) occurring moderately - with moderate proportion in contacts

(3) occurring scantily - with low proportion in contacts

(4) occurring scantily - contacts not recorded

(B) Species consumed disproportionately to their occurrence : 
Avoided :

(1) occurring numerously - with moderate proportion in contacts

(2) occurring numerously - with low proportion in contacts

(3) occurring moderately - with low proportion in contacts

(4) occurring numerously and moderately - no contacts recorded Preferred :

(5) occurring moderately - with considerable proportion in contacts

(6) occurring scantily - with moderate proportion in contacts

Markedly preferred

(7) occurring scantily - with considerable proportion in contacts

Species which were not included in phytosociological lists on account of their sporadic occurrence, but were recorded as being cropped by roe deer, were also taken into consideration in the analysis.

\subsection{Description of the Feeding Habits of Roe Deer Plantation ( $1-4$ years old)}

In this age class of tree stand 23 species of trees, bushes and shrubs and 93 species of herb plants were found to occur, but roe deer cropped only 17 species of ligneous and 49 species of herb plants. The total number of contacts recorded was $32,158,14.1 \%$ of which consisted of ligneous plants, $81.8 \%$ herb plants, $3.8 \%$ grasses and sedges and $0.2 \%$ fungi. Only 3 contacts were recorded in the group of mosses and lichens. Among herb plants the following dominate: Rubus sp. $-19.3 \%$, Fragaria vesca - 14.7\% and Anemone nemorosa - 12.4\%. The greatest proportion among ligneous plants was formed by Carpinus betulus $5.4 \%$ and Populus tremula $-2.6 \%$ (Table 2).

Analysis of plants from the aspect of their consumption by roe deer (supply - demand) showed (Table 4) that in the plantation the animals chiefly cropped commonly occurring plants (A 1 and 2). They form $84.4 \%$ of all contacts (Table 6). Food is supplemented by plants from group A 3 , the small proportion of which in contacts is connected with their moderate occurrence. They form $3.0 \%$ of contacts. Food is also supplemented by plants from groups B 1, 2, $3\left(3.8^{0} / 0\right)$. Both the number of contacts and species of herb plants consumed in the plantation show that this age class of tree stand forms the main supply of herb laye: plant food for roe deer.

\section{Young Tree Stand (12-22 years old)}

The phytosociological lists contain 20 species of ligneous and 88 species of herb plants, but roe deer cropped only 18 ligneous species $(17+$ Cerasus sp. not included in the lists) and 27 herb species. The combined number of contacts was $8,123,40.5 \%$ of which were ligneous plants and $54.3 \%$ herb plants. Grasses and sedges form $4.7 \%$ and fungi $0.2 \%$ of all contacts 
Tabie 2

Number of roe deer's contacts with plants $(n)$ compared with the value of the coefficient of abundance (D) of occurrrence of these plants in the fresh deciduous forest.

No Species

\begin{tabular}{lll} 
& Total & \\
\hline n & $\%$ & $\mathrm{D}$
\end{tabular}

\begin{tabular}{ccc}
$\substack{\text { Young tree stand } \\
\text { (thicket) }}$ \\
\hline $\mathrm{n}$ & $\%$ & $D$
\end{tabular}

Partly wooded fallow land

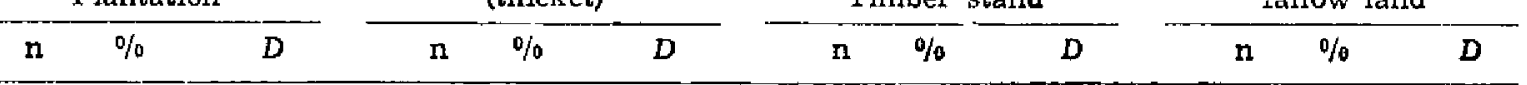

TREES, SHRUBS AND DWARF - SHRUBS

i. Corpinus betulus

2. Salix caprea

3. Poptulus tremula

4. Vaccinium myrtillus

5. Quercus robur

6. Betula verrucosa

7. Sorbus aucuparia

8. Betula pubescens

9. Acer platanoides

10. Malus silvestris

11. Cerasus sp.

12. Evonymus verrucosa

13. Cytisus ruthenicus

14. Corylus aveltana

15. Vaccinium vitis-idaea

16. Callana vulgaris

17. Quercus rubra

18. Genista tinctoria

19. Pirola secunda

20. Tilita cordata

21. Alnus glutinosa

22. Daphne mezereum

23. Frangula alnus

24. Picea excelsa

25. Pinus silvestris

26. Fraxinus excetsior

27. Acer negundo

28. Prunus sp.

29. Juniperus communis

30. Viburnum opulus

\begin{tabular}{|c|c|c|c|c|c|c|c|}
\hline 16937 & 13.9 & $\begin{array}{l}b \\
c\end{array}$ & $\begin{array}{r}450 \\
50\end{array}$ & 1731 & 5.4 & $\begin{array}{l}b \\
c\end{array}$ & $\begin{array}{r}42 \\
104\end{array}$ \\
\hline \multirow{2}{*}{7631} & 6.3 & $\mathrm{~b}$ & 9 & 103 & 0.3 & $b$ & 4 \\
\hline & & $c$ & 41 & & & $c$ & 129 \\
\hline \multirow[t]{2}{*}{3464} & 2.8 & $\mathrm{~b}$ & 17 & 850 & 2.6 & $\mathrm{~b}$ & 8 \\
\hline & & c & 10 & & & c & 21 \\
\hline 2250 & 1.8 & & 115 & 515 & 1.6 & & 100 \\
\hline \multirow[t]{2}{*}{2189} & 1.8 & b & 26 & 157 & 0.5 & b & - \\
\hline & & c & 19 & & & c & 33 \\
\hline \multirow[t]{2}{*}{1892} & 1.5 & b & 410 & 346 & 1.1 & b & 37 \\
\hline & & c & 85 & & & $\mathrm{c}$ & 275 \\
\hline \multirow[t]{2}{*}{1819} & 1.5 & $b$ & 59 & 537 & 1.6 & b & 54 \\
\hline & & c & 28 & & & c & 25 \\
\hline \multirow[t]{2}{*}{760} & 0.6 & $\mathrm{~b}$ & 3 & 85 & 0.3 & $\mathrm{~b}$ & 4 \\
\hline & & c & 5 & & & c & 8 \\
\hline \multirow[t]{2}{*}{398} & 0.3 & $\mathrm{~b}$ & 9 & 62 & 0.2 & $b$ & - \\
\hline & & $c$ & 44 & & & $c$ & 29 \\
\hline \multirow[t]{2}{*}{366} & 0.3 & b & 4 & 30 & + & b & - \\
\hline & & c & 1 & & & c & - \\
\hline 184 & 0.1 & c & 8 & 8 & + & c & 8 \\
\hline 133 & 0.1 & b & 1 & 0 & 0 & b & - \\
\hline 119 & 0.1 & & 22 & 75 & 0.2 & & 46 \\
\hline \multirow[t]{2}{*}{115} & $\neq$. & b & 56 & 1 & + & $\mathrm{b}$ & - \\
\hline & & c & 6 & & & $\mathrm{c}$ & 8 \\
\hline 98 & + & & 9 & 23 & $+t$ & & 4 \\
\hline 85 & + & & 3 & 0 & 0 & & 8 \\
\hline \multirow[t]{2}{*}{70} & + & b & - & 1 & + & b & - \\
\hline & & c & 1 & & & c & - \\
\hline 65 & $\div$ & & 32 & 27 & + & & 29 \\
\hline 55 & + & & 23 & 6 & + & & 4 \\
\hline \multirow[t]{2}{*}{29} & + & b & 1 & 0 & 0 & b & 4 \\
\hline & & c & 1 & & & $c$ & - \\
\hline 10 & + & c & - & 0 & 0 & $c$ & - \\
\hline \multirow[t]{2}{*}{10} & + & b & 18 & 0 & 0 & $b$ & 4 \\
\hline & & c & 24 & & & $\mathrm{c}$ & $\begin{array}{r}17 \\
4\end{array}$ \\
\hline 9 & + & $\mathrm{c}$ & 1 & 0 & 0 & $c$ & \\
\hline 6 & + & $\begin{array}{l}b \\
c\end{array}$ & $\begin{array}{r}169 \\
19\end{array}$ & 0 & 0 & $\begin{array}{l}\mathrm{b} \\
\mathrm{c}\end{array}$ & $\overline{21}$ \\
\hline \multirow[t]{2}{*}{0} & - & b & 5 & 0 & - & $\mathbf{b}$ & - \\
\hline & & c & 86 & & & $c$ & 279 \\
\hline 0 & - & $c$ & 4 & 0 & - & $c$ & - \\
\hline
\end{tabular}

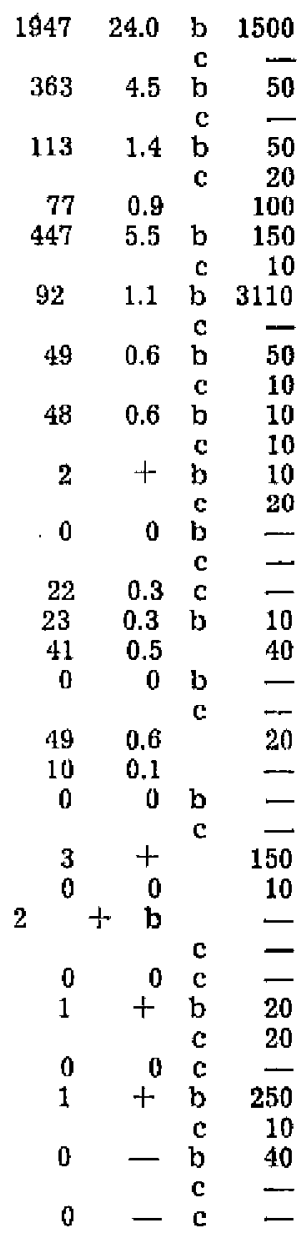

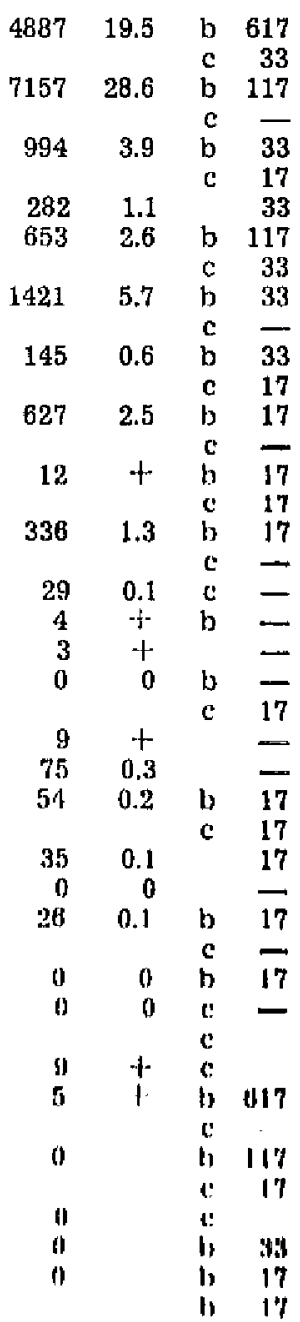

$\begin{array}{llll}0 & - & c & 1\end{array}$

$0-10 \quad 10$ 


\begin{tabular}{|c|c|c|c|c|}
\hline 1. & Oxalis acetosella & 24633 & 20.2 & 729 \\
\hline 2. & Anemone nemorosa & 13518 & 11.1 & 977 \\
\hline 3. & Viola sp. & 8485 & 7.0 & \\
\hline & Viola riviniana & & & 95 \\
\hline & Viola silvestris & & & 22 \\
\hline & Viola canina & & & 27 \\
\hline & Viola rupestris & & & 5 \\
\hline 4. & & 7146 & 5.9 & 1 \\
\hline & $\begin{array}{l}\text { Rubus saxatilis } \\
\text { Rubus sp. }\end{array}$ & 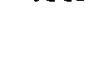 & & $\begin{array}{r}197 \\
20\end{array}$ \\
\hline & Rubus idaeus & & & 827 \\
\hline 5. & Fragatia vesca & 6090 & 5.0 & 620 \\
\hline 6. & Veronica chamaedrys & 3434 & 2.8 & 365 \\
\hline & $\begin{array}{l}\text { Veronica serpyllifolia } \\
\text { Veronica arvensis }\end{array}$ & & & $\begin{array}{r}10 \\
3\end{array}$ \\
\hline & $\begin{array}{l}\text { Veronica arvensis } \\
\text { Veronica anagallis }\end{array}$ & & & $\begin{array}{l}3 \\
1\end{array}$ \\
\hline 7. & Rumex tenuifolius & 3431 & 2.8 & 95 \\
\hline & $\begin{array}{l}\text { Rumex acetosa } \\
\text { Rumex acetosella }\end{array}$ & & & 3 \\
\hline 8. & Melampyrum nemorosum & $174 \pi$ & 1.4 & 4 \\
\hline 9. & Achillea millefolium & 1269 & 1.0 & 14 \\
\hline 10. & Mycelis muralis & 988 & 0.8 & 40 \\
\hline 11. & Stellaria holostea & 858 & 0.7 & 42 \\
\hline 12. & Galium sp. & 619 & 0.5 & \\
\hline & Galium schultezii & & & 8 \\
\hline & Galium mollugo & & & 6 \\
\hline & Galium boreale & & & 9 \\
\hline & Galium vernum & & & 1 \\
\hline 13. & Vicia sp. & 610 & 0.5 & \\
\hline & $\begin{array}{l}\text { Vicia cracca } \\
\text { Yicia cassubica }\end{array}$ & & & $\begin{array}{l}27 \\
14\end{array}$ \\
\hline & Vicia sepium & & & 38 \\
\hline & Vicia tetrasperma & & & - \\
\hline 14. & Lathyrus vernus & 498 & 0.4 & 23 \\
\hline 15. & Veronica officinalis & 479 & 0.4 & 199 \\
\hline 16. & Majanthemum bifolium & 468 & 0.4 & 347 \\
\hline 17. & Lotus corniculatus & 467 & 0.4 & - \\
\hline 13. & Stellaria graminea & 327 & 0.3 & 10 \\
\hline 19. & Asperula odorata & $32 \pi$ & 0.3 & 245 \\
\hline 20. & Hepatica nobilis & 323 & 0.3 & 31 \\
\hline 21. & Erigeron canadensis & 311 & 0.2 & 40 \\
\hline 22. & Plantago lanceolata & 308 & 0.2 & 13 \\
\hline 23. & Taraxacum officinale & 303 & 0.2 & 32 \\
\hline 24. & $\begin{array}{l}\text { Chamaenerion } \\
\text { angustifolium }\end{array}$ & 278 & 0.2 & 54 \\
\hline 25. & Ajuga reptans & 259 & 0.2 & 174 \\
\hline 26. & Trifolium sp. & 238 & 0.2 & \\
\hline & Trifolium repens & & & 8 \\
\hline & Trifolium pratense & & & 10 \\
\hline & Trifolium alpestre & & & 19 \\
\hline & Trifolium medium & & & 13 \\
\hline 27. & Melandrium album & 192 & 0.1 & - \\
\hline 28. & Ranunculus repens & 188 & 0.1 & 42 \\
\hline 29. & Potentilla argentea & 183 & 0.1 & 3 \\
\hline 30. & Hypericum perforatum & 134 & 0.1 & 60 \\
\hline 31. & Solidago virga-aurea & 126 & 0.1 & 33 \\
\hline 32. & Convolvulus arvensis & 104 & + & - \\
\hline 33. & Melampyrum pratense & 88 & + & - \\
\hline 34. & Aquilegid vulgaris & 87 & + & 28 \\
\hline $3 \overline{5}$. & Serratula tinctoria & $8 \overline{5}$ & + & 20 \\
\hline 36. & Lathyrus silvester & 83 & + & 17 \\
\hline 37. & Geranium silvaticum & 66 & \pm & 5 \\
\hline & Geranium robertianum & & & 5 \\
\hline & Geranium pusillum & & & $\mathbf{1}$ \\
\hline 38. & Knautia arvensis & 58 & + & - \\
\hline 39. & Polygonum convolvulus & 54 & + & - \\
\hline 40. & Lychnis flos-cuculi & 52 & + & 1 \\
\hline 41. & Hieracium pilosella & 49 & + & 26 \\
\hline 42. & Phyteuma spicatum & 47 & + & 4 \\
\hline 43. & Lysimachia vulgaris & 46 & + & 1 \\
\hline 44. & Melittis melyssophyllum & 42 & + & 35 \\
\hline 45. & Galeobdolon luteum & 35 & + & 8 \\
\hline 46. & Prunella vulgaris & 25 & + & 8 \\
\hline 47. & Moehringia trinervia & 24 & + & 29 \\
\hline 48 . & Senecio vernalis & 23 & 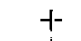 & 4 \\
\hline 49. & Thalictrum minus & 23 & + & 11 \\
\hline 50. & Arabis arenosa & 20 & + & 19 \\
\hline 51. & Cirsium arvense & 20 & + & 31 \\
\hline 52. & Potentilla erecta & 18 & + & 15 \\
\hline 53. & Ranunculus acer & 17 & + & 14 \\
\hline 54. & Torilis japonica & 16 & + & 9 \\
\hline 55. & Hieracium pratense & 16 & + & 8 \\
\hline 56. & Campanula persicifolia & 15 & + & 19 \\
\hline 57. & Pteridium aquilinum & 13 & + & 205 \\
\hline 58. & Ranunculus lanuginosus & 13 & + & 5 \\
\hline 59. & Senecio silvaticus & 10 & + & 17 \\
\hline 60. & Convallaria maialis & 6 & + & 82 \\
\hline 61. & Dianthus deltoides & 3 & + & - \\
\hline 62. & Erigeron acer & 3 & + & 1 \\
\hline 63. & Hypochoeris radicata & 3 & + & 10 \\
\hline 64. & Lilium martagon & 3 & + & 35 \\
\hline 65. & Viola tricolor & 3 & + & - \\
\hline 66. & Aegopodium podagraria & 2 & \pm & 3 \\
\hline 67. & Chrysanthemum & 2 & + & - \\
\hline 68. & $\begin{array}{l}\text { leucanthemum } \\
\text { Aruncus silvester }\end{array}$ & 1 & + & - \\
\hline 69 . & Cerastium vulgatum & 1 & + & 8 \\
\hline 70. & Hieracium umbellatum & 1 & + & 15 \\
\hline 71. & Ranunculus cassubicus & 1 & + & - \\
\hline & Subtotal & 79482 & 65.3 & \\
\hline
\end{tabular}


1. Dentaria bulbifera

2. Sanicula europaea

3. Trientalis europaea

4. Dryopteris spinulosa

5. Polygonatum odoratum

6. Epilobittm montantim

7. Urtica dioica

8. Galeopsis bifida

9. Cirsium lanceolatum

10. Scrophularia nodosa

12. Ginaphalium silvaticum

12. Giaphalium sil

14. Calamintha vulgaris

15. Betonica officinalis

16. Digitalis grandiflora

17. Athyrium filix-femina

18. Leontodon autumnaliss

19. Campanula rapunculoides

20. Plantanthera bifolia

21. Artemisia vulgaris

22. Lathyrus niger

23. Dryopteris filix-mas

24. Geum urbanum

25. Lapsana communis

26. Primula officinalis

27. Anthericum ramosum

28. Peucedanum oreoselinum

29. Hierccium murorum

30. Campanula cervicaria

31. Polygonatum multiflorum

32. Galeopsis tetrahit

33. Actaea spicata

34. Thallctrum

aquilegitfolium

35. Hupericum montanum

36. Arabidopsis thaliane

37. Chenopodium album

38. Potentilla anserina.

39. Tripleurospermum inodorum

40. Chelidonium maius

41. Linaria vulgaris

42. Arnica montana

43. Pulmonaria angustifalia

44. Astragaius danicus

45. Botrychium lunaria

46. Geum rivale

47. Monotropa hypopitys

48. Meracium lachenali

49. Mentha arvensis

50. Ranunculus polyanthemos

51. Pirola minor

52. Jasione montana

53. Oenothera biennis

54. Agrimonia odorat

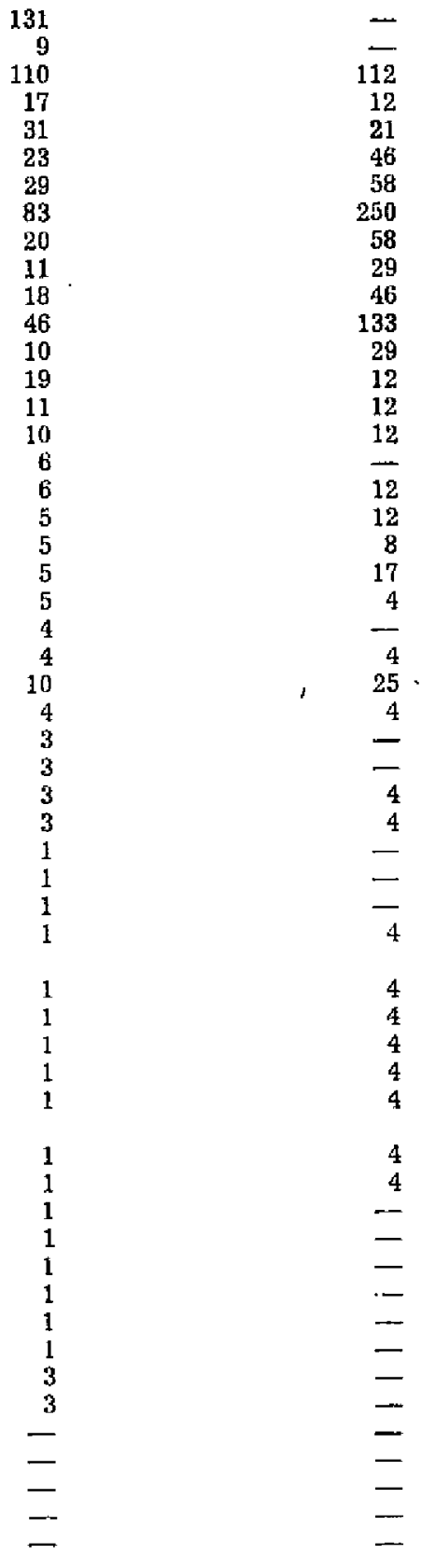

Grimonia odorata

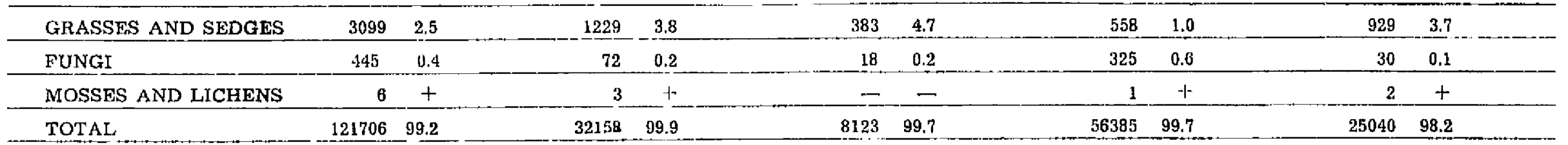

$b$ - bush layer, $c-$ herb layer, +- percentage of specles less than $0.1 \%$ 
recorded in the young tree stand. Carpinus betulus $(24.0 \%)$ and Anemone nemorosa $(32.1 \%$ ) were most frequently cropped (Table 2).

Species numerously occurring in the young tree stand predominate in contacts $(75.8 \%$ ) (Table 4 and 6 ). Species readily cropped by roe deer, but occurring less numerously, form a further $17.1 \%$ of contacts these are chiefly Stellaria holostea $-7.7 \%$, Salix caprea $-4.5 \%$, Lathyrus vernus $-1.8 \%$ and Populus tremula $-1.4 \%$. Food consumed in the young tree stand was supplemented by plants occurring and cropped to a small extent $\left(2.4^{\%} \%\right.$ of contacts) and species not readily consumed by roe deer $\left(4.2^{\circ} / 0\right.$ of contacts). Both the high percentage of ligneous plants in the total number of contacts recorded in the young tree stand $(40.5 \%)$, and the relatively small number of herb plants consumed by roe deer, show that the animals most readily consume browse in this class of tree stand.

\section{Table 3}

Key to defining the numbers of different plant species in the area and the percentage formed in the roe deer's food.

\begin{tabular}{cccc}
\hline $\begin{array}{c}\text { Coefficient of } \\
\text { abundance }(D)\end{array}$ & $\begin{array}{c}\text { Numbers of } \\
\text { plant in area }\end{array}$ & $\begin{array}{c}\% \text { in } \\
\text { contacts }\end{array}$ & $\begin{array}{c}\text { Proportion } \\
\text { in food }\end{array}$ \\
\hline $\begin{array}{l}1-49 \\
50-99\end{array}$ & few & $+1-0.4$ & few \\
100 and over & moderate & $0.5-0.9$ & moderate \\
\hline
\end{tabular}

$1+=$ percentage less than $0.1 \%$

Old Tree Stand (118-158 years old)

21 species of ligneous and 59 species of herb plants occur in the old tree stand, but contacts were recorded only with 17 ligneous species and 35 herb species. The total number of contacts was 56,385, 24.8\% of which were herbs, $1.0 \%$ grasses and sedges and $0.6 \%$ fungi. Oxalis acetosella - 41.0\%, Carpinus betulus - 14.8\%, Anemone nemorosa $12.2 \%$ and Viola $\mathrm{sp}$. - $10.7 \%$ predominate in the food consumed by roe deer in the old tree stand (Table 2).

Analysis of plants in respect of their consumption by roe deer (Table 4 and 6) showed that $86.0 \%$ of contacts was found for numerously occurring plants. Species readily cropped, but occurring less numerously, form a further $9.0 \%$ of contacts. Food consumed in the old tree stand is supplemented by plants growing in very great numbers $\left(2.3^{*} \%\right)$ and occurring numerously or moderately, but not readily consumed by roe deer. Contacts with them formed $1.8^{0} \%$.

Fallow Land (fallow + young tree stand from 10-25 years old)

A total of 26 species of trees, bushes and shrubs and 66 species of herb plants were recorded on the fallow land. The roe deer cropped 20 
Table 4

Division of plants according to the tuse made of them by roe deer.

A. Species consumed in proportion to occurrence
B. Species consumed disproportionately to occurrence

PLANTATION

1.

Carpinus betulus

Vaccinium myrtilus

Betula verrucosa

Rubus sp.

Fragaria vesca

Rumex tenuifolius

Veronica chamaedrys

Viola sp.

Veronica officinalis

Erigeron canadensis

2.

Grasses and sedges

3.

Trifolium sp.

Betula pubescens

Acer platanoides

Malus silvestris

Genista tinctoria

Cerasus sp.

Pirola secunda

Corulus avellana

Quercus rubra

Oralis acetosella

Lathyrus vernus

Serratula tinctoria

Lathyrus silvester

Lychnis flos-cuculi

Aquilegia vulgaris

Solidago virga-aureo

Galium sp.

Senecio vernalis

Thalictrum minus

Melandrium album

Phyteuma spicata

Torylis japonica

Hieracium pratense

Geranium silvaticum

Campanula persicifolia

Plantago lanceolata

Ranunculus lanuginosus

Achillea millefolium

Potentilla erecta

Ranunculus acet

Hepatica nobilis

Hypochoeris radicata

4.

Lilium martagon

Calluna vulgaris

Tilia cordata
1.

Vicia sp.

Chamaenerion angustifolium

Ratinculus repens

2.

Ajuga reptans

Salix caprea

Hupericum perforatum

Majanthemum bifolium

3.

Aspertula odorata

Cytisus ruthenicus

Senecio silvaticus

Arabis arenosa

Cirsitum arvense

Stellaria holostea

4.

Pteridium aquilinum

Pinus silvestris

Trientalis auropaea

Urtica dioica

Galeopsis bifiala

Cirsium lanceolatum

Gnaphalitum silvaticum

Funaria hygrometrica

5.

Sorbus aucuparia

6.

Quercus robur

Taraxacum officinate

Mucelis murcilis

7.

Populus tremula

Stellaria graminea

Melampurum nemorosum 
A. Species consumed in proportion to occurrence
B. Species consumed disproportionately to occurrence

Daphne mezereum

Frangula alnus

41 species of herbs

YOUNG THEE STAND (THICKET)

1.

Carpinus betulus

Quercus robut

Betula verrucosa

Anemone nemorosa

Oxalis acetosella

Viola sp.

Rubus sp.

2.

Grasses and sedges

3.

Galium sp.

Cerasus sp.

Evonymus verrucosa

Calluna vulgaris

Acer platanoides

Tilia cordata

Daphne mezereum

Hepatica nobilis

Galeobdolon luteum

Aspertula odorata

Geranium silvaticum

Mycelis muralis

Melampyrum nemorosum

Rumex obtusifolius

Potentitla erecta

Achillea millefolium

4.

Lathyrus silvester

Pirola secunda

51 species of herbs
1.

Vaccinium murtillus

Fragaria vesca

Veronica chamaedrys

Vicia sp.

2.

Genista tinctoria

Picea excelsa

Trifolium sp.

Taraxacum officinale

Chamaenerion angustifolium

3.

Convallaria maialts

Sorbus aucuparia

Ranunculus acet

Aquilegia vulgaris

4.

Cirsium arvense

Veronica officinalis

Majanthemum bifolium

Ajuga reptans

Ranunculus repens

Solidago virga-aurea

Hieracium pilosella

5.

Salix caprea

Populus tremula

Stellarta holostea

6.

Vaccinitum vitis-idaea

Cytisus ruthenicus

Betula pubescens

7.

Lathyrus vernus

TIMBER STAND

1.

Carpinus betulus

Vaccinium myrtillus

Sorbus aucuparia

Oxalis acetosella

Viola sp.

Anemone nemorosa

2.

Grasses and sedges

Acer platanoides

Rubus sp.

Hepatica nobilis
1 .

Majanthemum bifolium

Asperula odorata

2.

3.

Corylus avellana

Daphne mezereum

Convallaria maialis

Fragaria vesca

Ajuga teptans 
A. Species consumed in proportion to occurrence

3.

Cerasus sp.

Evonymus verrucosa

Pirola secunda

Betula verrucosa

Vaccinium vitis-idaea

Quercus rubra

Alnus glutinosa

Salix caprea

Tilia cordata

Lathyrus vernus

Stellaria holostea

Galium sp.

Veronica officinalis

Solidago virga-aurea

Phyteuma spicata

Ranunculus repens

Geranium silvaticum

Melittis melissophyllum

Lathyrus silvester

Rumex tenuifolius

Vicia sp.

Stellaria graminea

Taraxacum officinale

Ranunculus lanuginosus

Aquilegia vulgaris

Galeobdolon luteum

Ranunctulus acer

Campanula persicifolia

Pteridium aquilinum

Hieracium umbellatum

4.

Ranunculus casstebicus

Betula pubescens

Fraxinus excelsior

Malus silvestris

22 species of herbs

FALLOW LAND PARTLY WOODED

1.

Carpinus betulus

Salix caprea

Quetcus robur

Fragaria vesca

Veronica chamaedrys

Rumex acetosella

Achitlea millefolium

Plantago lanceolata

2.

Grasses and sedges

Sorbus aucuparia

3.

Viola sp.

Acer platanoides

Cerasus sp.
B. Species consumed

disproportionately to occurrence

4.

5.

6.

Picea excelsa

Dentaria bulbifera

Trientalis europaea

7.

Populus tremula

Quercus robut

Mycelis muralis

Melampyrum nemorosum
1.

Rubus sp.

2.

Potentilla argentea

Picea excelsa

Anemone nemorosa

Majanthemum bifolium

Convolvulus arvensis

Hieracium pilosella

3.

Pteridium aquilinum

4.

5.

Trifolium sp.

Pinus silvestris

Vicia sp. 
A. Species consumed in proportion to occurrence
B. Species consumed disproportionately to occurrence
Evonymus vertucosa

Cytisus ruthenicus

Vaccinium vitis-idaea

Calluna vulgaris

Quercus rubra

Genista tinctoria

Tilia cordata

Frangula alnus

Mycelis mutalis

Stellaria hotostea

Lathyrus vernus

Veronica officinatis

Asperula odorata

Hepatica nobilis

Erigeron canadensis

Taraxacum officinale

Ajuga reptans

Ranunculus tepens

Hypericum perforatum

Solidago vitga-aurea

Melampyrum pratense

Stellaria graminea

Knatutia arvensis

Polygonum convolvulus

Phyteuma spicato

Lysimachia vulgaris

Moehringia trinervia

Potentilla erecta

Ranunculus acer

Convallaria maialis

Dianthus deltoides

Erigeron acer

Viola tricolor

Aegopodium podagraria

Chrysanthemum

laucanthemum

Aruncus silvester

4.

Cerastium vulgatum

Corylus avellana

Daphne mezereum

Acer negundo

Prunus sp.

Juniperus communis

Pirola minor

15 species of herbs
6.

7.

Gatium sp.

Melandrium ailbum

Populus tremula

Vaccinium myrtillus

Betula verrucosa

Betula pubescens

Malus silvestris

Oxalis acetosella

Lotus corniculatus

Melampyrum nemorosum

A. 1-occurring numerously with considerable percentage in contacts

2 - moderately numerous with moderate percentage in contacts

3 - occurring scantily with small percentage in contacts

4 - occurring scantily - not recorded in contacts

B. Avoided

1 - occurring numerously with moderate percentage in contacts

$2-$ occurring numerously with small percentage in contacts

3 - occurring moderately with small percentage in contacts

4 - occurring numerously and moderately - not recoded in contacts

Explanation continued on p. 94 . 
ligneous species and 50 herb species. The combined number of contacts was $25,040,66.7 \%$ of which related to ligneous and $27.7 \%$ to herbs, $3.7 \%$ to grasses and sedges and $0.1 \%$ to fungi. Among the total number of contacts recorded there among ligneous species Salix caprea and others predominated $-28.6^{6} / \mathrm{ll}$, and Carpinus betulus $-19.5 \%$ and among herbs Achillea millefolium $-5.0^{\mathrm{o}} \mathrm{n}$, Oxalis acetosella $-4.4^{\mathrm{o}} \%$ and Fragaria vesca $-4.2^{n / 0}$ (Table 2).

Analysis of plants in respect of their consumption by roe deer showed (Table 4 and 6 ) that $69.4 \%$ of contacts took place with species growing abundantly and moderately. Plants readily cropped by roe deer, but occurring less abundantly, form a further $24.5^{\circ} \%$. Food consumed in the fallow land was supplemented by species occurring scantily in the area $(3.0 \%$ of contacts) and occurring numerously or moderately, but not readily cropped by roe deer $(2.6 \%)$.

\subsection{Qualitative and Quantitative Cousumption of Food Resources by Roe Deer}

Jointly for the study area 155 species of ligneous and herb plant species were found to occur, but 97 species were recorded in the roe deer's food (Table 2). Consumption of food resources in respect of the number of species in tree stands of different age and in the fallow land is presented in Table 5, from which it can be seen that most of the species growing numerously or very abundantly are included in the roe deer's diet. The majority of the species with which no contacts were recorded are characterized by scanty occurrence. Among plants occurring numerously, but not consumed in the given age class of tree stand or fallow land, it is the species for which no contacts were recorded over the whole study area which predominate. These are: Dentaria bulbifera, Trientalis europaea, Urtica dioica, Galeobsis bifida, Cirsium lanceolata and Gnaphalium silvaticum.

The foregoing justifies the assumption that moderate consumption by roe deer of the supply of species in a mixed deciduous forest (about $63^{\circ} \%$ ) is due to the more scanty occurrence of a considerable number of the plant species.

Table 4, explanations concluded.

Preferred

5 - occurring moderately with considerable percentage in contacts

6 - occurring scantily with moderate percentage in contacts

Greatly preferred

7 -occurring scantily with moderate percentage in contacts 
Quantitative consumption of food resources is shown in Table 6, from which it can be seen that the decided majority of contacts relate to plants allocated to the group of species not excessively consumed in relation to the abundance of their occurrence $(75.0 \%-91.2 \%$ of contacts). These are chiefly species cropped in proportion to the abundance of their occurrence $\left(72.4^{0} \%-88.3 \%\right.$ of contacts).

Species particularly intensively consumed, and thus distinctly preferred by roe deer, form from $8.5^{0} \%$ to $24.5^{\mathrm{g}} / \mathrm{t}$ of contacts in successive age classes of tree stand and in the fallow land. This group includes 7 species in the plantation of young tree stand, 5 species in the old tree stand and 10 species in fallow land (Table 4). Among trees Populus tremula is preferred in all age classes, Quercus robur in the plantation

Table 5

Use made of plants species by roe deer.

\begin{tabular}{|c|c|c|c|c|c|c|c|}
\hline \multirow{3}{*}{$\begin{array}{l}\text { Age class } \\
\text { of tree stand }\end{array}$} & \multicolumn{7}{|c|}{ Number of species } \\
\hline & \multicolumn{4}{|c|}{$\begin{array}{l}\text { Occurring scantily } \\
(D \text { maximum }=50)\end{array}$} & \multicolumn{3}{|c|}{$\begin{array}{l}\text { Occurring numerously } \\
(D \text { over } 51)\end{array}$} \\
\hline & $\begin{array}{c}\text { In } \\
\text { area }\end{array}$ & $\begin{array}{c}\text { In } \\
\text { diet }\end{array}$ & $\begin{array}{l}\text { No. } 0 \\
D \leqslant 25 \\
\end{array}$ & $\frac{5}{i-50}$ & $\begin{array}{l}\text { In } \\
\text { area }\end{array}$ & $\begin{array}{l}\text { In } \\
\text { diet }\end{array}$ & $\begin{array}{c}\text { No. } \\
\text { contacts }\end{array}$ \\
\hline \multirow{5}{*}{$\begin{array}{l}\text { Plantation } \\
\text { Thicket } \\
\text { Timber stand } \\
\text { Fallow land } \\
\text { partly wooded }\end{array}$} & 83 & 39 & 37 & 7 & 33 & 27 & 6 \\
\hline & 81 & 24 & 38 & 19 & 27 & 21 & 6 \\
\hline & 60 & 35 & 21 & 4 & 20 & 17 & 3 \\
\hline & & & & & & & \\
\hline & 69 & 48 & 18 & 3 & 23 & 22 & 1 \\
\hline
\end{tabular}

and old tree stand, Betula pubescens in the young tree stand and fallow land. It must be emphasised that a considerable number of contacts with oak and aspen in the old tree stand consist of twigs and leaves blown down by wind from the upper parts of trees and in the case of oaks, also with acorns. In the group of herbs those particularly preferred are Mycelis muralis in the plantation and old tree stand, Stellaria graminea in the plantation, Lathyrus vernus in the young tree stand, Oxalis acetosella and Lotus corniculatus in the fallow land, and Melampyrum nemorosum in the plantation, old tree stand and the fallow land.

Species not readily consumed by roe deer form from $1.8 \%$ to $4.2 \%$ of contacts. This group includes 21 plant species in the plantation, 20 in the young tree stand and 10 respectively in the old tree stand and fallow land. The phenomenon of unwilling consumption by these animals of certain components of the available food resources can be seen most clearly by the example of those species which, regardless of their abundance of occurrence in successive age classes (in some cases very considerable), form a small or even negligible proportion of contacts. These 
are: Pinus silvestris, Majanthemum bifolium, Asperula odorata, Genista tinctoria, Hypericum perforatum, Cirsium arvense, Pteridium aquilinum, Convallaria maialis, Ranunculus acer, Ranunculus repens, Daphne mezereum and Ajuga repens.

By comparison of intensity of feeding by roe deer on different species of plants and of their abundance of occurrence in the area it is possible to establish the following: it is a characteristic feature of food relations of roe deer in a mixed deciduous forest that demand is defined by supply. This is shown by the fact that from more than 70 to $90^{\circ} \%$ of contacts

Table 6

Percentage of plants from different zero categories in contacts recorded in different biotopes.

\begin{tabular}{|c|c|c|c|c|c|}
\hline \multirow{2}{*}{\multicolumn{2}{|c|}{$\begin{array}{l}\text { Utilization } \\
\text { (categories } \\
\text { of plants) }\end{array}$}} & \multicolumn{3}{|c|}{ Age class of tree stand } & \multirow{2}{*}{$\begin{array}{l}\text { Partly wooded } \\
\text { fallow land }\end{array}$} \\
\hline & & Plantation & Thicket & Timber stand & \\
\hline & $\begin{array}{l}\text { A 1, A 2 } \\
\text { A } 3 \text {, } \\
\text { B 1, B 2, B } 3 \\
\text { Subtotal } \\
\text { B 5, B 6, B } 7 \\
\text { Total } 1\end{array}$ & $\begin{array}{r}84.4 \\
3.0 \\
3.8 \\
91.2 \\
8.5 \\
99.7\end{array}$ & $\begin{array}{r}75.8 \\
2.4 \\
4.2 \\
82.4 \\
17.1 \\
99.5\end{array}$ & $\begin{array}{r}86.0 \\
2.3 \\
1.8 \\
90.1 \\
9.0 \\
99.1\end{array}$ & $\begin{array}{r}69.4 \\
3.0 \\
2.6 \\
75.0 \\
24.5 \\
99.5\end{array}$ \\
\hline
\end{tabular}

1 Sum total $\% \%$ given without species with percentage in contacts of less than $0.1 \%$.

I - not excessively consumed

A. 1. occurring numerously with high percentage in contacts,

2. occuring moderately with moderate percentage in contacts,

3. occurring scantily with small percentage in contacts,

B. 1. occurring numerously with moderate percentage in contacts,

2. occurring numerously with small percentage in contacts,

3. occurring moderately with small percentage in contacts,

II - intensively consumed

B. 5. occurring moderately with considerable percentage in contacts,

6. occurring scantily with considerable percentage in contacts,

7. occurring scantily with moderate percentage in contacts.

were recorded for the group of plants consumed in proportion to their occurrence, while species, for which it may be concluded that demand for them does not exceed supply in the area, form from about 8 to about $24 \%$ of contacts and thus far less than their proportion in coformation of the picture of trophic relations.

\section{YEARLY FEEDING CYCLE OF ROE DEER}

A description is given below of the yearly feeding cycle of roe deer on groups and species of plants, based on the whole material, jointly for all age classes of tree stand and fallow land. Standardized units of 
the animals' feeding, i.e. "bits" have been used for this purpose. The system for conversion of observation units (contacts) into feeding-units, bits, has been described in section 2 (Material and methods).

Data on the yearly cycle of feeding by roe deer were obtained by examining the composition of the animals' diet in 19 feeding periods (Table 7).

On account of the different number of bits recorded in successive feeding periods, the whole of the data is presented in the form of percentages. The sum total of all bits recorded in a given feeding period was taken as $100 \%$ (Fig. 1).

Table 7

Division of year into feeding periods.

\begin{tabular}{|c|c|c|c|c|c|}
\hline Period & Date & Period & Date & Period & Date \\
\hline $\begin{array}{l}. \\
2 . \\
3 . \\
4 . \\
5 . \\
6 .\end{array}$ & $\begin{array}{r}1 . I V-10 . I V \\
11 . I V-20 . I V \\
21 . I V-30 . I V \\
1 . V-10 . \mathrm{V} \\
11 . \mathrm{V}-20 . \mathrm{V} \\
21 . \mathrm{V}-31 . \mathrm{V}\end{array}$ & $\begin{array}{r}7 . \\
8 . \\
9 . \\
10 . \\
11 . \\
12 .\end{array}$ & $\begin{array}{l}\text { 1.VI-10.VI } \\
11 . \mathrm{VI}-20 . \mathrm{VI} \\
21 . \mathrm{VI}-30 . \mathrm{VI} \\
\text { 1.VII-10.VII } \\
\text { 11.VII-20.VII } \\
\text { 21.VII-31.VII }\end{array}$ & $\begin{array}{l}13 . \\
14 . \\
15 . \\
16 . \\
17 . \\
18 . A . \\
18 . \mathrm{B} \text {. }\end{array}$ & $\begin{array}{c}\text { 1.VIII-15.VIII } \\
\text { 16.VIII-31.VIII } \\
\text { 1.IX-30.IX } \\
1, \mathrm{X}-31 . \mathrm{X} \\
\text { 1.XI - up to snowfall } \\
\text { Months with snow cover } \\
\text { Winter days without snow }\end{array}$ \\
\hline
\end{tabular}

In discussing the roe deer's diet in winter, food consumed from supplementary winter food supplies has been omitted, as this question has been discussed separately (Kossak, in press).

\subsection{Variations in the Proportion of Groups of Plants In the Roe Deer's Diet over the Yearly Cycle}

Trees, Bushes, Shrubs

Ligneous plants occur in the roe deer's diet throughout the year, but their proportion in the animals' food varies in successive feeding periods (Fig. 1). Fewest bits are recorded after snow has disappeared (second ten-day period of April — second ten-day period of May) $-10 \%$. The subsequent four feeding periods are characterized by increase in the proportion of ligneous species (end of May and June) to about 25\%, and also its relative stabilization. In periods from 10 to 12 inclusive (July and first half of August) the proportion of this group increases gradually to about $56^{\%} \%$. During the second half of August, in September and October (periods 14-16 inclusive) the proportion of ligneous species is maintained on a level of $58-60 \%$ of bits. During period $17-$ late autum (November) there is a periodical decrease in the roe deer's feeding on ligneous plants (about $48 \%$ of bits). Period 18A (with persisting snow cover) is characterized by decided predominance of ligneous food in the roe deer's diet $\left(99^{\circ} \%\right)$, whereas in sub-period 18B (winter thaws 
exposing the herb layer) the roe deer's feeding on this group of plants decreases to $16 \%$ of bits. The intensive feeding of roe deer on ligneous plants recorded in winter continues to the end of the first 10 days of

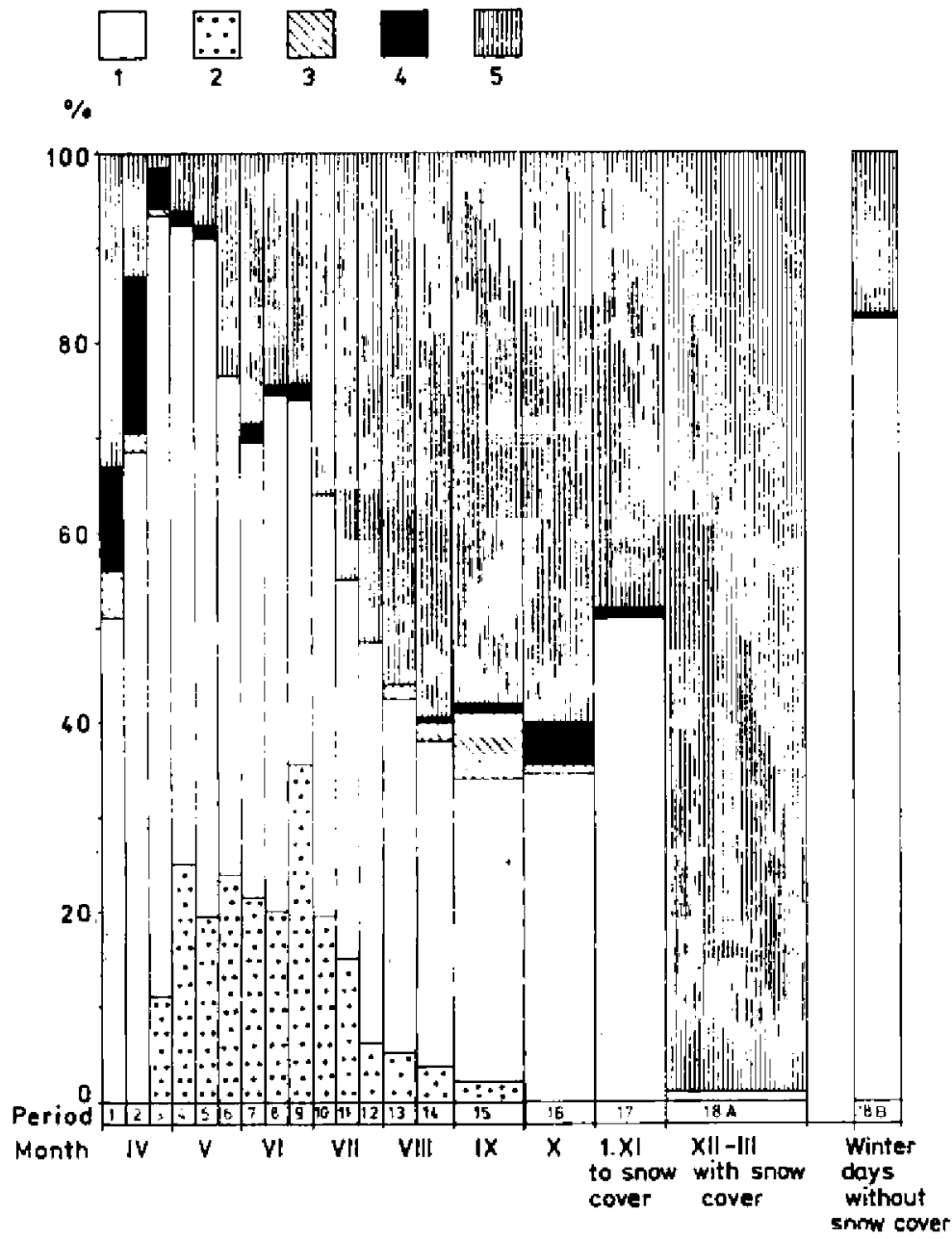

Fig. 1. Percentage of groups of plants in the roe deer's diet over the yearly cycle. 1 - herb layer plants, 2 - generative parts of herb layer plants, 3 - fungi, 4 grasses and sedges, 5 - trees, bushes, shrubs. $1-18 \mathrm{~B}$ - feeding periods (cf. Table 7 ).

April (pericid I), when this group forms $33^{\circ} \%$ of all bits during this feeding period.

\section{Herb Plants}

Roe degr feed on herbs throughout the year, but the proportion formed by this group of plants in the animals' diet is subject to considerable 
variations (Fig. 1). After snow disappears and plant growth begins there is a rapid increase in the percentage of herbs in the roe deer's diet. This increase takes place through the first and second 10-day period of April, to reach the annual maximum during the third 10-day period (about $93 \%$ of bits). This high proportion of herbs in the animals' diet is maintained, with slight fluctuations, up to the second 10-day period of May inclusive. During the third 10-day period of this month it decreases to about $75 \%$, followed by a stabilized period lasting up to the end of June. In July and August the proportion of herbs in the roe deer's diet gradually decreases, to become stabilized once more in September on a level of about $35 \%$. This state is maintained up to the end of October. In November the proportion of herbs transitorily increases to about $51 \%$ of bits, probably as the result of the decreased attraction of ligneous food (lack of leaves) in favour of herbs characterized by a long growing period. In winter sporadic bits from the herb plant group were recorded only when the snow cover was not very deep, while on days of winter thaws exposing the herb layer the proportion of herbs increases to about $82 \%$ of bits.

The generative parts of herbs (flowers and fruits) play a considerable part in the roe deer's diet, being cropped over 12 feeding periods (third 10-day period of April - end of September). The proportion of generative parts in the roe deer's diet rapidly increases at the start of the growing season (end of April - about 11\%), is relatively stabilized on a level of $20-25$ bits between the first 10-day period of May and first 10-day period of July, with a maximum occurring at the end of June $(33 \%)$, and slowly decreases from the second 10-day period of July (about $15 \%$ ) to the end of September (about $2 \%$ ). In October roe deer were recorded as having sporadically cropped plants in process of the generative phase.

\section{Grasses and Sedges}

The plants in this group play their chief part in the roe deer's diet in spring and autumn (Fig. 1). They appear in the animals' diet after snow disappears and form $10 \%$ of bits during the first, and about $15 \%$ in the second, 10-day periods of April. In subsequent feeding periods their proportion decreases to about $2 \%$ and is maintained on this level up to the end of June. From the first half of July to mid-August the animals were not found to crop these plants, which re-appeared in the animals' diet during the second half of August and reached about $5 \%$ in bits consumed by roe deer in September. In late autumn (November) they still form about $1 \%$ of all bits. Sporadic cropping of grasses and sedges was recorded on winter days when snow cover disappears. 


\section{Fungi}

Twice during the course of the year fungi form an important part of the roe deer's diet. The first short period when the animals consume them occurs in April, the maximum ( $5 \%$ in bits) being recorded during the first, $2 \%$ during the second and only $0.5 \%$ during the third, 10-day periods of this month. The animals were not found to consume them in May. This group re-appears in the roe deer's food during the first half of August (about $1 \%$ of bits). The annual maximum of feeding on fungi occurs in September (about $7 \%$ of bits). Sporadic consumption of fungi was recorded in winter when snow covered the ground.

\subsection{Variations in the Numbers of Ligneous and Herb Plant Species in the Roe Deer's Diet over the Yearly Cycle}

The number of ligneous and herb plant species is subject to considerable variation in the roe deer's diet over the annual cycle (Fig. 2), with

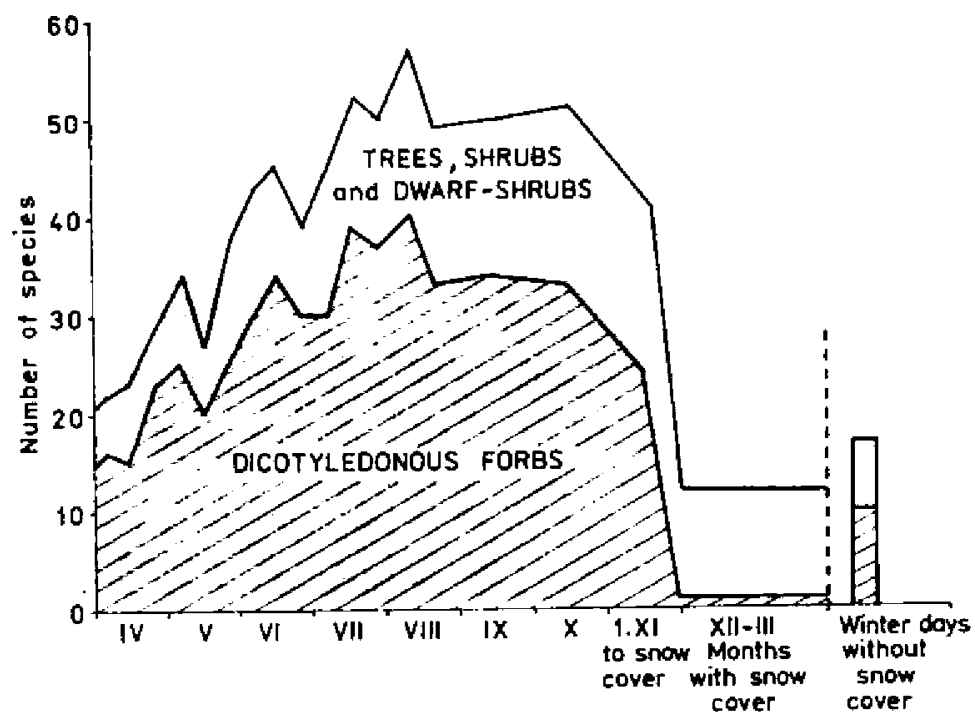

Fig. 2. Number of plant species in the roe deer's diet over the yearly cycle.

a distinct tendency to enrichment of their diet in spring and summer (annual maximum - 57 species in the first half of August) and impoverishment in autumn and winter (annual minimum - 11 species during the time the ground is covered with snow).

The spring diet of roe deer contains the smallest number of ligneous plant species (less than 10 in April and the two first 10-day periods of May). In subsequent months there is a tendency to increase the variety 
of species consumed, and in the first half of August their number become stable at a level of $16-17$, continuing until snow begins to fall. While snow cover persists roe deer feed on ligneous species and during winter thaws exposing the herb layer, on 7 .

The number of herbs cropped by roe deer is subject to considerable variations over the yearly cycle and, as in the case of ligneous plants,
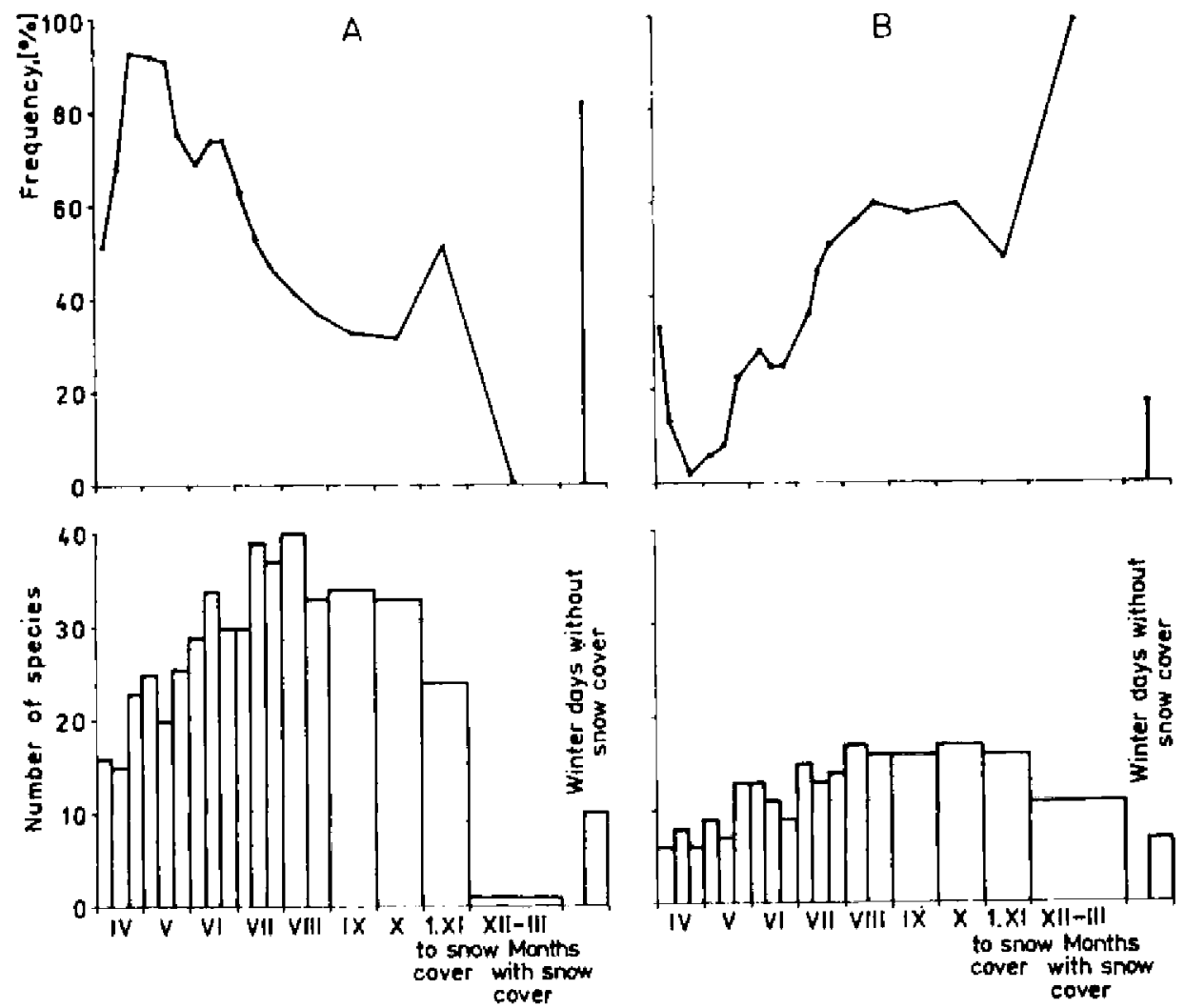

Fig. 3. Comparison of the percentage of groups of plants and number of species in the roe deer's diet over the yearly cycle.

A - herb layer plants, B - trees, bushes, shrubs.

there is a tendency to enrich the diet in respect of number of species during the spring-summer period, and to impoverish it at other times of the year. Disappearance of the snow cover makes it possible for roe deer to feed on 15-16 species (April). This number increases in subsequent months to become established for the period from mid-July to mid-August on a level of 37 to 40 species. As from the second half 
of August the number of species in their diet decreases by 7 up to the end of October and by a further 9 in November. When snow falls roe deer cease feeding on herb plants (only sporadic cropping of one species was recorded). On days of winter thaws, when snow disappears roe deer feed on 10 species of herbs.

It is clear from the above discussion that the proportion of the given group of plants in the roe deer's food is not necessarily connected with the number of species on which they feed (Fig, 3). For instance the lower percentage of bits from ligneous plants in their diet (end of April - 2\%) consisted of 6 species - the same number that formed $33 \%$ during the first 10 days of April. Similarly during the winter months with persisting snow cover, when ligneous plants form as much as $99^{\circ} \%$ of bits, roe deer cropped only 11 species of tree, bush and shrub species.

There was, however, coincidence in the number of species and proportion of ligneous species in the diet during the summer-autumn period (August-October) of maximum feeding (about $60^{\circ} / \mathrm{o}$ of bits), consisting in cropping $16-17$ species.

In the group of herb plants the discrepancies between proportion of this group in the roe deer's diet and the number of species consumed are distinct. Greatest intensity of feeding by deer on herbs, occurring at the end of April and in May, is not connected with variety of diet (only $20-25$ species). The greatest variety in their food was recorded from mid-July to mid-August ( $37-40$ species), when the proportion of this group in the roe deer's diet shows a tendency to decrease.

\subsection{Composition of the Roe Deer's Food over the Yearly Cyele}

Taking similarities and differences in the composition of the roe deer's diet in successive feeding periods as a basis (Fig, 4), the description of the year's food consumption by these animals is as follows:

The roe deer's diet in April and the first 20 days of May is characterized by the increasing and later decreasing proportion in it of Oxalis acetosellsa, Fragaria vesca, Anemone nemorosa, Viola sp. and the group of grasses and sedges. In mid-April it contains larger amounts of Stellaria holostea, and as from mid-May Rubus sp. Apart from intensive cropping of Vaccinium myrtillus at the beginning of April and the relatively stable but small proportion of Carpinus betulus, it does not contain any important amounts of other ligneous plant species.

From the end of May there are changes in the roe deer's diet. Its composition up to the end of June is as follows: the proportion of Oxalis acetosella, Fragaria vesca, Anemone nemorosa decreases con- 
siderably, there are no grasses or sedges, but Veronica chamaedrys and Rumex tenuifolius appear in greater quantities. It continues to contain large amounts of Rubus sp, and up to the middle of June, also Viola sp. At the end of June the proportion of Lathyrus vernus increases. During this time, in addition to Carpinus betulus, other ligneous species begin to appear in the animals' diet (Populus tremula, Sorbus aucuparia, Salix caprea, Quercus robur and Vaccinium myrtillus).

From the first days of July to the end of August the proportion of ligneous species, i.e. Carpinus betulus and Salix caprea, increases in their diet, and of herb species, Oxalis acetosella and from the end of July Viola sp. During the first 20 days of July Lathyrus vernus and Melampyrum pratense are readily consumed, and during this time the animals feed less on Rubus sp. and Rumex tenuifolius. At the end of August Fragaria vesca disappears from their diet, while Achillea millefolium and Acer platanoides appear. Among ligneous species the following additionally occur in the animals' diet at this time: Sorbus aucuparia, Populus tremula, Betula pubescens, Betula verrucosa, Quercus robur and Vaccinium myrtillus.

In September Salix caprea predominates in the roe deer's diet, while the proportion of Carpinus betulus decreases. Ligneous species also occurring in their diet include Populus tremula, Betula verrucosa, Quercus robur together with the first acorns, and Sorbus aucuparia. Among herb plants Rubus sp., Lathyrus vernus and Viola sp. occur, and in quantities greater than during the summer months - Oxalis acetosella. Fungi are included in their diet in September.

From the first days of October up to the time snow falls (early December) Oxalis acetosella and Carpinus betulus predominate in the roe deer's diet. In October roe deer cease feeding on Salix caprea, while grasses and sedges appear transitorily, and the proportion of acorns greatly increases at this time, particularly in November. In addition to the above species, Betula verrucosa and Viola sp. were also recorded in the animals' diet.

With the appearance of lasting snow cover and during the time it persists (early December - end of March) Carpinus betulus predominates in the roe deer's diet. In addition to this Populus tremula and Vaccinium myrtillus are also eaten, but in far smaller quantities. If thaws occur during this time, combined with disappearance of the snow cover, the composition of the roe deer's diet changes radically - it consists almost entirely of Oxalis acetosella, supplemented by small amounts of Carpinus betulus, Vaccinium myrtillus, Populus tremula and Viola sp.

During the growing season the generative parts of plants form a con- 

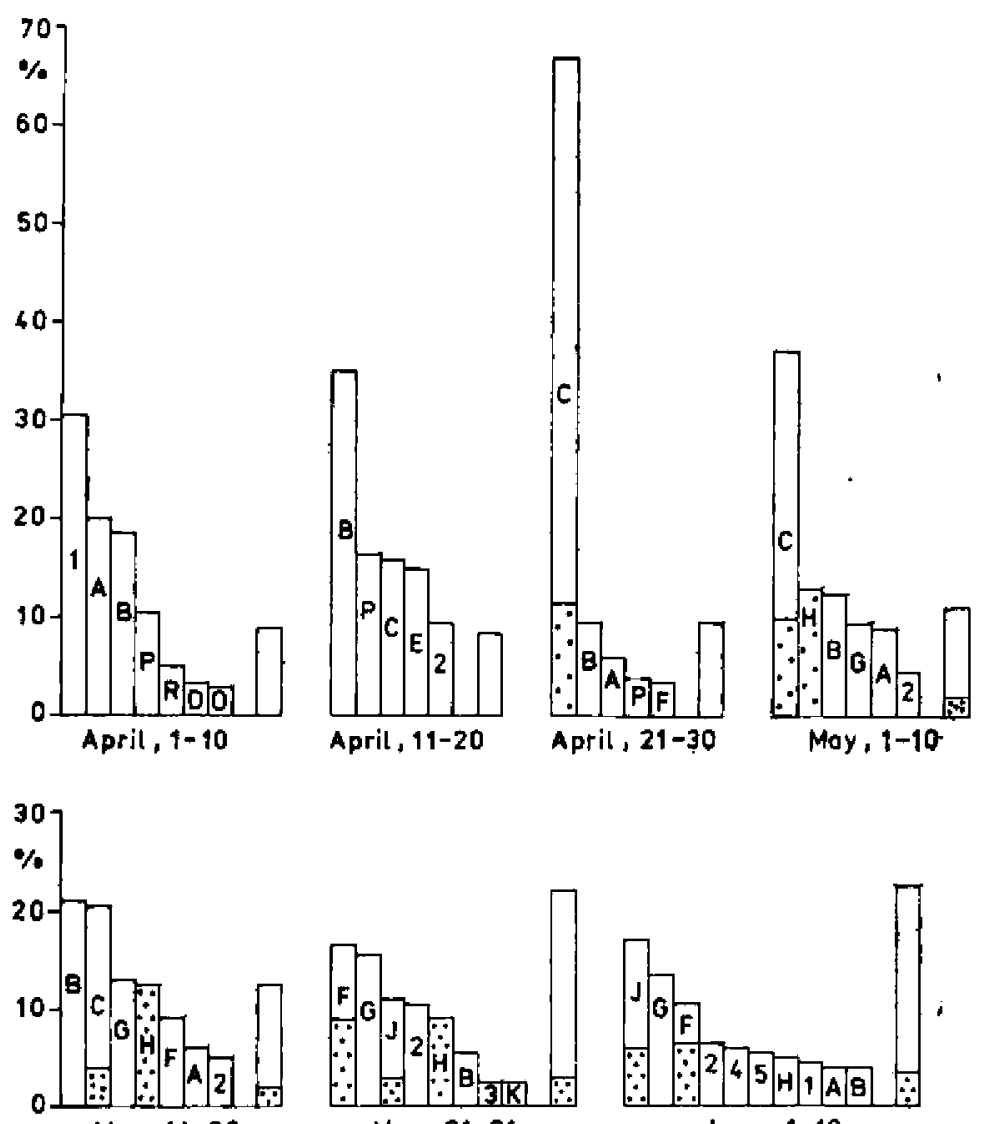

May, 11-20
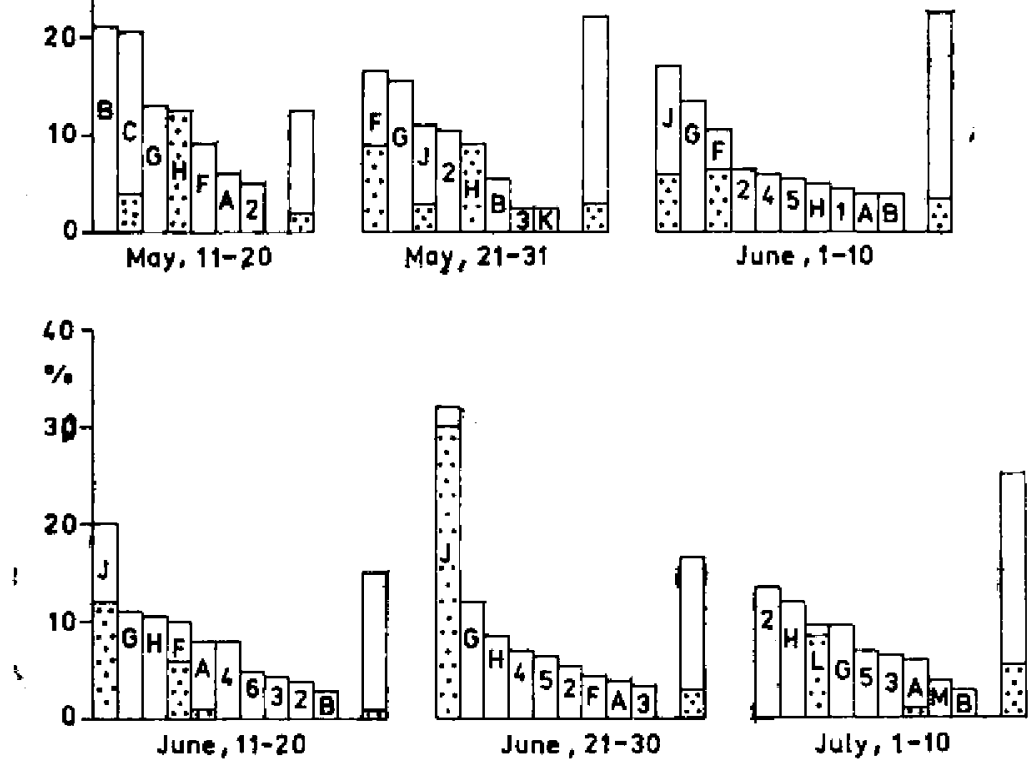

Fig. 4. Composition of the roe deer's food over the yearly cycle.

1. Vaccinium myrtillus, 2. Carpinus betulus, 3. Salix caprea and Salix sp., 4. Populus tremula, 5. Sorbus aucuparia, 6. Quercus robur, 7. Acer platanoides, 8. Betula verrucosa, 9. Betula pubescens. A. Fragaria vesca, B. Oxalis acetosella, C. Anemone nemorosa, D. Stellaria graminea, E. Stellaria holostea, F. Veronica chamaedrys, 

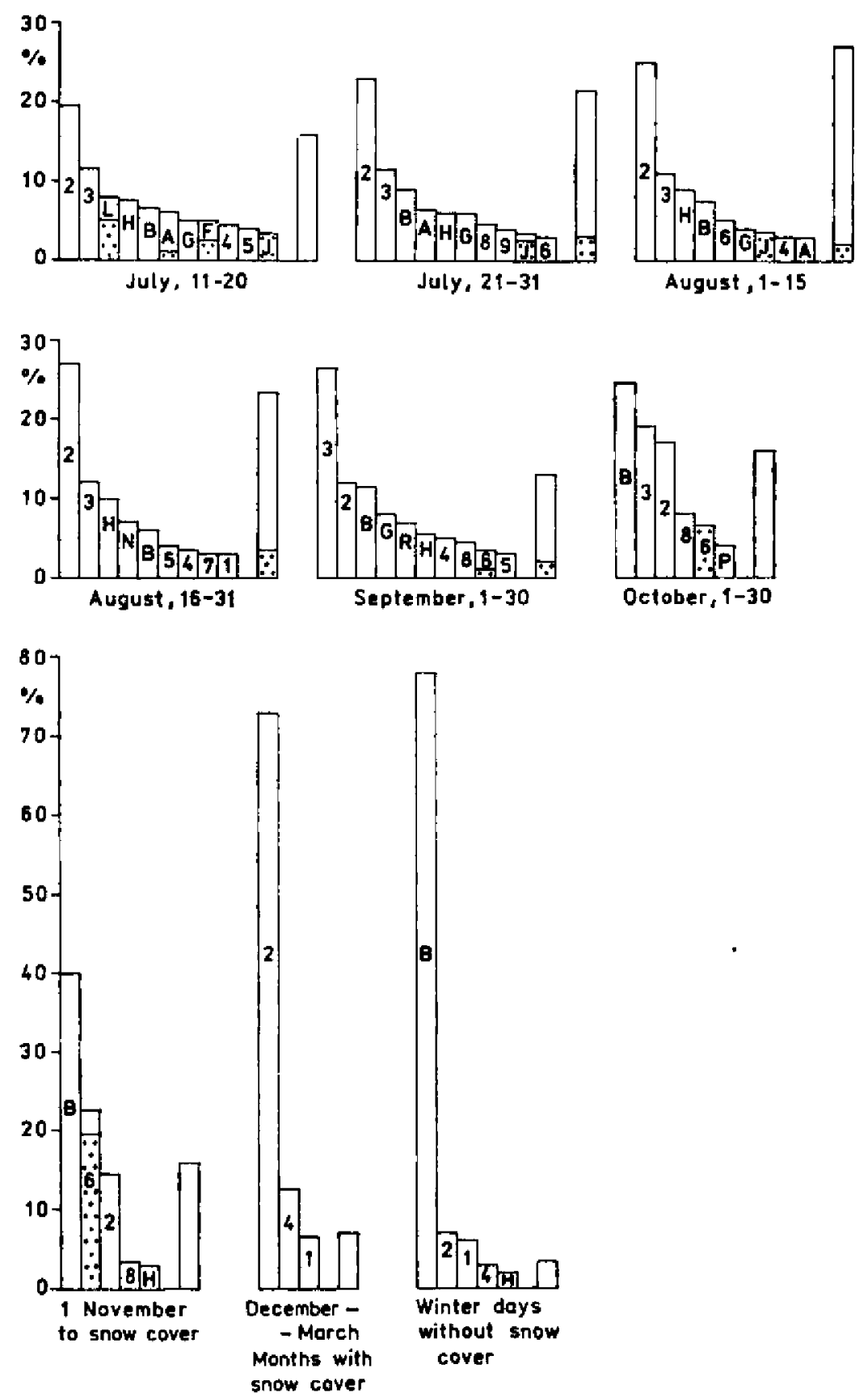

G. Rubus sp., H. Viola sp., I. Rumex tenuifolius, K. Lathyrus vernus, L. Melampyrum pratense, M. Mycelis muralis, N. Achillea millefolium, O. Veronica officinalis, P. Grasses and sedges, R. Fungi.

The dotted parts of the columns indicate the proportion of the generative parts of plants. The final column contains species with proportion less than $3 \%$. 
siderable proportion of the roe deer's diet (flowers, fruits and seeds of the following species) : Anemone nemorosa, Viola sp., Veronica chamaedrys, Oxalis acetosella, Rumex tenuifolius, Fragaria vesca, Melampyrum pratense, Quercus robur and other species not mentioned individually in figure 4 on account of the small percentage they form in the diet as a whole: Mycelis muralis, Asperula odorata, Achillea millefolium, Erigeron canadensis, Hepatica nobilis, Lathyrus vernus, Lotus corniculatus, Majanthemum bifolium (avoided during the flowering period, preferred during the fruiting period), Melampyrum nemorosum, Plantago lanceolata, Stellaria holostea, Taraxacum officinale, Vicia sp. and certain grasses and sedges. It may thus be assumed that plants in the generative phase form particularly attractive food for roe deer. This assumption was tested using Anemone nemorosa and Oxalis acetosella as samples, on account of their considerable proportion in the roe deer's diet, abundant flowering and the ease with which flowers and leaves cropped by roe deer can be counted. The way in which data were collected has been given in section 2 (Material and methods). Differences in the percentage of flowering individuals in the area and consumed by animals in their food were tested by means of the $\chi^{2}$ test. It can be seen from table 8 that these differences are statistically highly significant, which shows that the animals prefer (that is, actively choose) flowering individuals of the two plant species. This preference is particularly strong in the case of Oxalis acetosella. In the case of Anemone nemorosa the above phenomenon occurred most distinctly in the plantation.

\subsection{Description of the Feeding Habits of Roe Deer on Some Ligneous Species, Herbs, Grasses and Sedges and on Fungi}

On the basis of data from reports on successive field observations and on material presented in the preceding sections, a description was made of the way roe deer feed on different plant species. Plants were selected for analysis solely on the amount of material collected. The following have been taken into account in the description: (a) annual distribution of the roe deer's consumption of a given species, drawn up from standardized units of the animals' feeding, termed bits, (b) intensity of feeding by roe deer on a given species in successive age classes of the tree stand and on fallow land, determined on the basis of recorded contacts of these animals in the field with the given species; (a) and (b) have been illustrated by diagrams in Fig. 5 . (c) the proportion, calculated from data in reports, of the generative parts in contacts with herbs, grasses and sedges, and the proportion of twigs with leaves and leaves only in contacts with ligneous species, (d) proportion of contacts with the given species in the sum total of contacts recorded in three successive 


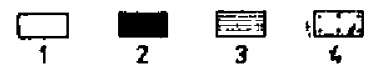
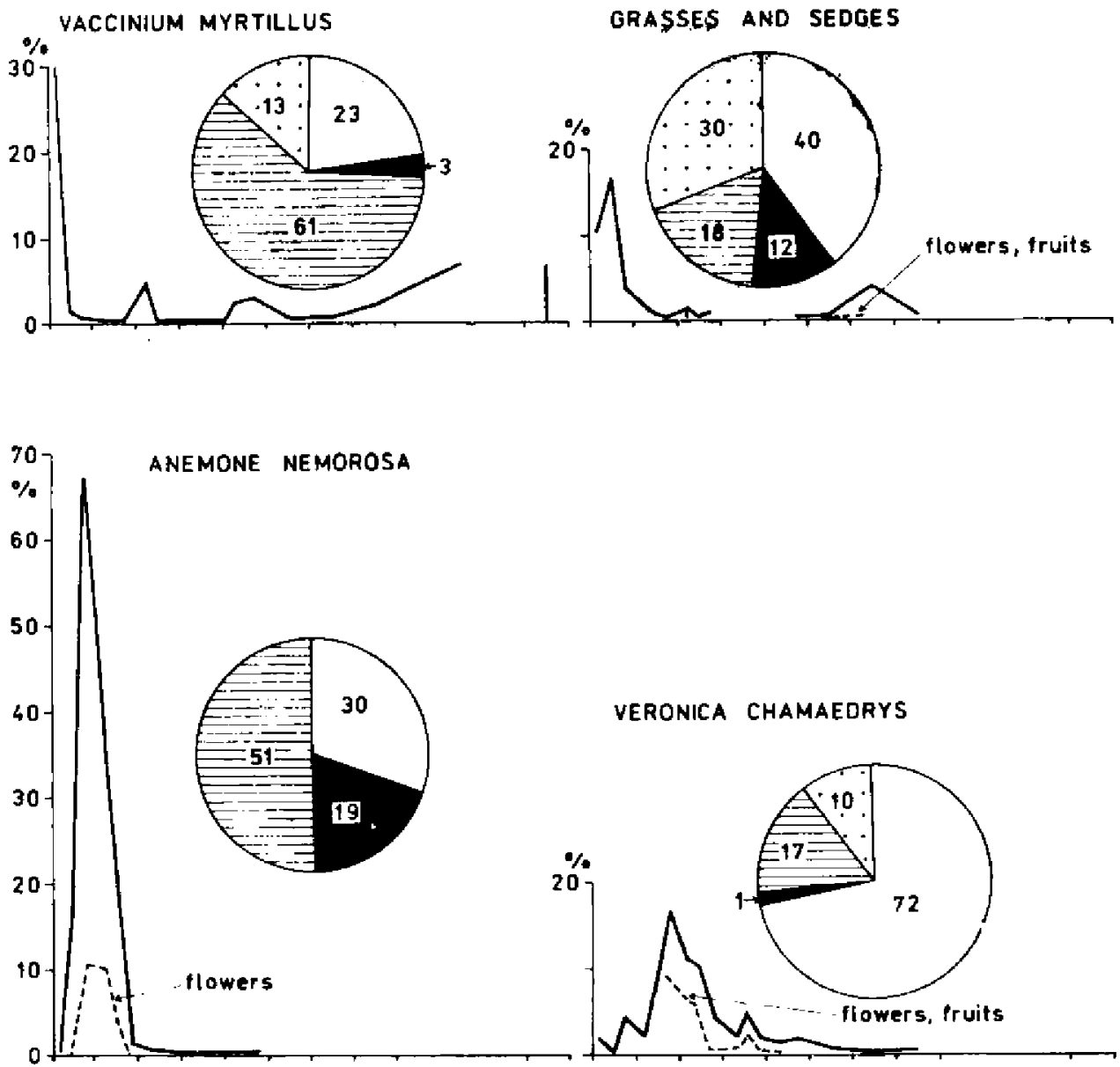

FRAGARIA. VE SCA

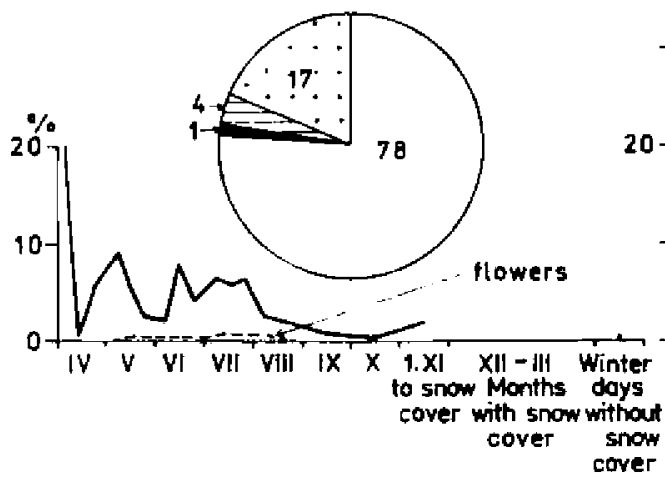

RUMEX SP.

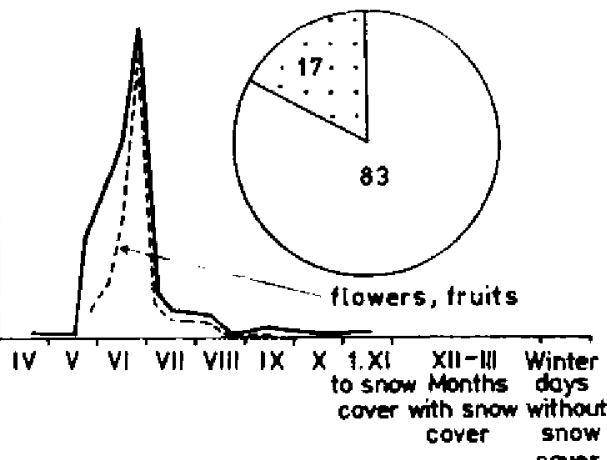




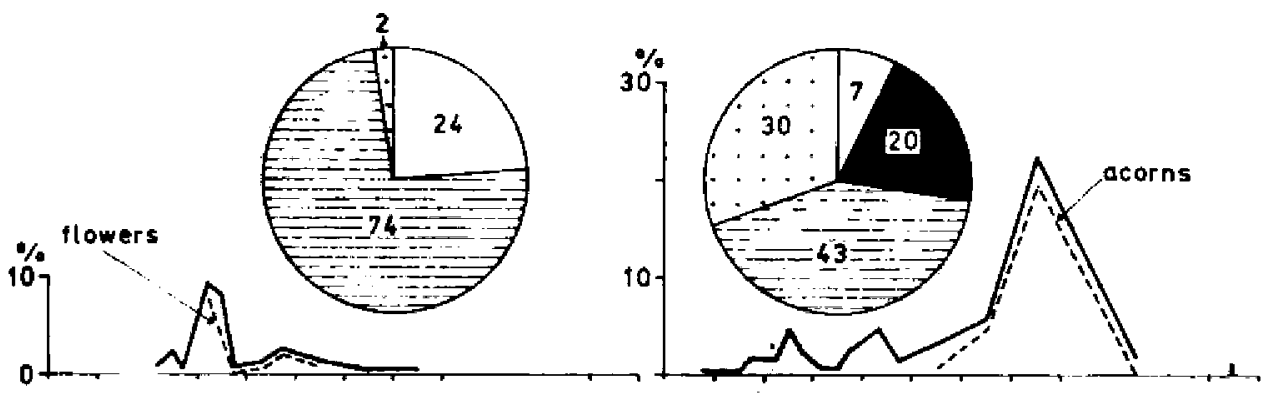

ACHILLEA MILLEFOLIUM

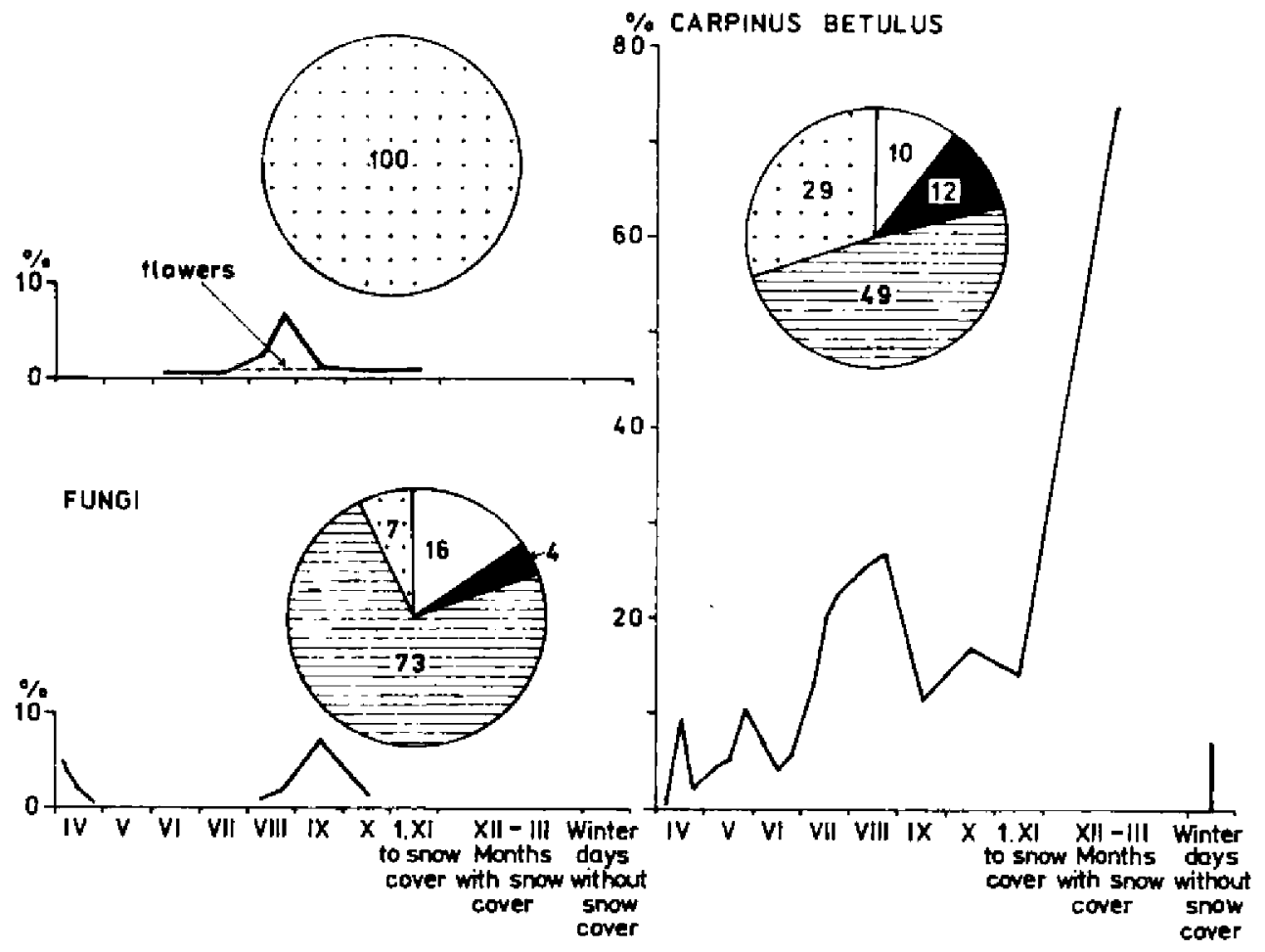

Fig. 5. Course of the roe deer's feeding on selected plant species.

Species discussed in order of the times in which they form a considerable part of the roe deer's diet. The yearly cycle of the roe deer's feeding on the given species is plotted on axis (the sum total of bits during one feeding period is taken as $100 \%$ ). Distribution of the roe ceer's feeding in tree stands of different age and in fallow land is given in a circle $(100 \%=$ sum total of all contacts recorded with the given species). Symbols: 1. Plantation $2-$ thicket, 3. timber stand, Fallow land partly wooded by young tree stand. 

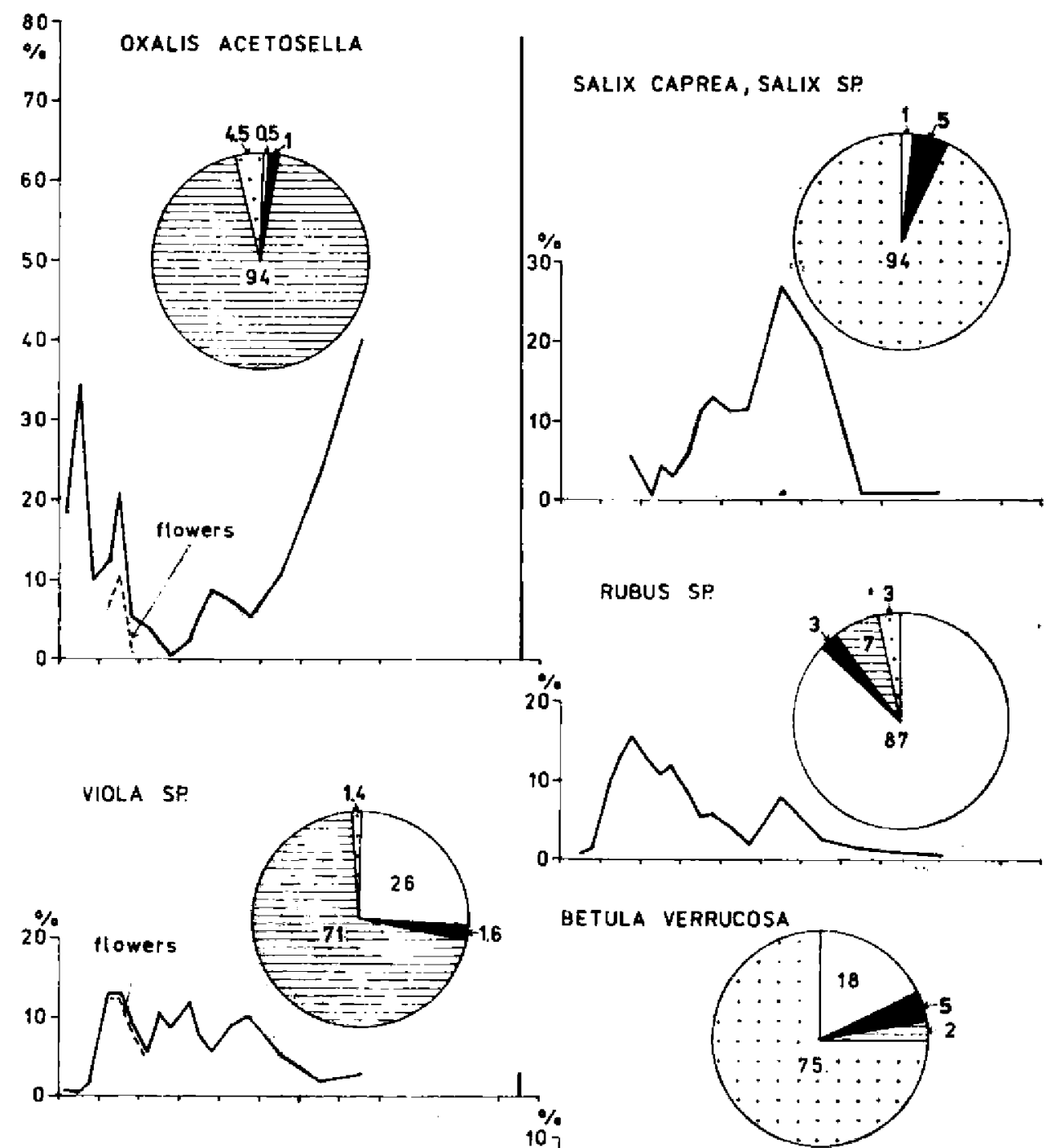

POPULUS TREMULA

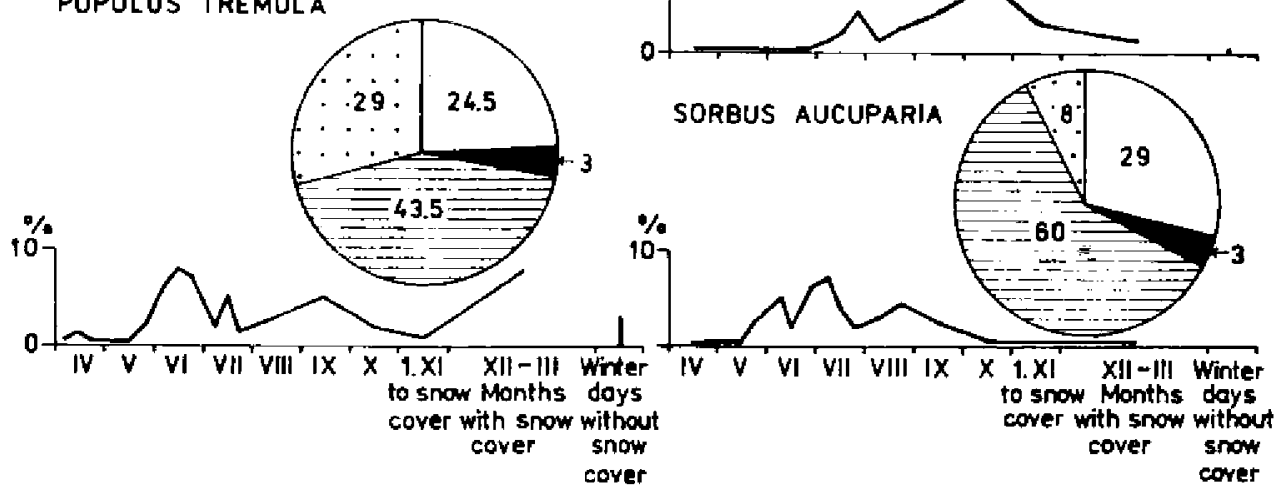


study years : 1976, 1977 and 1978. Data from 1976 were collected chiefly in the fallow land bearing a self-sown tree stand. (c) and (d) have been presented in the descriptive part.

During the early spring period Vaccinium myrtillus, Anemone nemorosa, Fragaria vesca and the group of grasses and sedges predominate in the roe deer's diet.

Vaccinium myrtillus is cropped by roe deer throughout the year, but the proportion it forms in their diet is only considerable at the beginning of April, when it is $30 \%$. During the growing season roe deer crop the leaf-bearing browse of this species. $V$. myrtillus was most often cropped in the old tree stand $(61 \%$ of contacts with this species) and in the plantation $(23 \%)$. In the sum total of contacts recorded in successive study years $V$. myrtillus formed $1.3,2.6$ and $0.6 \%$.

Anemone nemorosa occurs in considerable amounts in the roe deer's diet in the pre-spring and early spring periods, and at the end of April

\section{Table 8}

Comparison of percentage of flowers and leaves in the herb layer and in the roe deer's food.

\begin{tabular}{|c|c|c|c|c|c|c|c|c|}
\hline & & & \multicolumn{4}{|c|}{ Anemone nemorosa } & \multicolumn{2}{|c|}{ Oxalis acetosella } \\
\hline & \multicolumn{2}{|c|}{ Plantation } & \multicolumn{2}{|c|}{ Thicket } & \multicolumn{2}{|c|}{ Timber stand } & \multicolumn{2}{|c|}{ Timber stand } \\
\hline & Flowers & Leaves & Flowers & Leaves & Flowers & Leaves & Flowers & Leaves \\
\hline \multicolumn{9}{|l|}{ In herb } \\
\hline layer & $\begin{array}{l}92 \\
223\end{array}$ & $\begin{array}{l}987 \\
536\end{array}$ & 113 & $\begin{array}{l}797 \\
1338\end{array}$ & 12 & 607 & 173 & 2177 \\
\hline In $\begin{array}{c}\text { diet } \\
\chi_{P}^{q}\end{array}$ & \multicolumn{2}{|c|}{$p<0.01$} & \multicolumn{2}{|c|}{$P<0.01$} & \multicolumn{2}{|c|}{$P<0.01$} & \multicolumn{2}{|c|}{$\begin{array}{c}375.9 \\
P<0.01\end{array}$} \\
\hline
\end{tabular}

forms about $67 \%$ of their diet. Flowering individuals are particularly readily consumed by roe deer in the plantation, where they form $26.5^{0} \%$ of contacts with this species, and in the young tree stand $(22.0 \%)$. In the old tree stand flowering individuals form $12.0 \%$ of contacts with $A$. nemorosa. The largest amounts of $A$. nemorosa were consumed by roe deer in the old tree stand $(51 \%)$ and plantation $(30 \%)$. In contacts recorded in successive years the percentage of $A$, nemorosa was respectively $0.06,13.8$ and $15.9^{\%} \%$.

Roe deer feed on Fragaria vesca throughout the year, except for the period with persistent snow cover. It is particularly intensively cropped at the beginning of April, when it forms $20 \%$ of their diet, but in other seasons it does not exceed $10 \%$. The generative parts of $F$. vesca form about $6 \%$ of contacts with this species in fallow land and about $2 \%$ in 
the plantation. $F$. vesca was most frequently consumed in the plantation (78\% of contacts with this species) and fallow land $(17 \%)$. In successive years $F$. vesca formed $3.5,4.2$ and $7.9 \%$ of all contacts.

Grasses and sedges are eaten in greater quantities by roe deer twice a year - in April when they form about $17 \%$ of their diet and in October (about $4 \%$ of their diet). The animals crop chiefly Carex hirta, Milium effusum and Lusula pilosa, which jointly form about $18 \%$ of contacts with this group of plants. The generative parts form $9.7 \%$ of contacts with grasses and sedges (in fallow land - 25.0\%, in the plantation 5.6). In the young and old tree stands roe deer were not observed to crop the generative parts. In successive years grasses and sedged formed $3.1,2.7$, and $1.4^{0} \%$ of all contacts.

Veronica chamaedrys forms an important component of the roe deer's diet in spring and early summer, when it forms about 9 to about $17 \%$ of their diet. It is cropped during the whole growing season, but its percentage in the animals' diet does not exceed $5 \%$. Generative parts form $26.6 \%$ of contacts with this species (young tree stand $-70.6 \%$, plantation - $31.9 \%$, old tree stand - 15.1\%). The animals were not observed to feed on the generative parts of this species in the fallow land. $V$. chamaedrys is eaten chiefly in the plantation $(72 \%$ of contacts with this species). In successive years $V$, chamaedrys formed $1.1,3.3$ and $3.4 \%$ of all contacts.

Rumex tenuifolius and Rumex acetosella form a considerable proportion of the roe deer's diet in June (maximum about $32 \%$ ). In April, and from .July to the end of their growing season, their importance in the animals ${ }^{+}$diet is slight. $65.5 \%$ of all contacts with $R$. tenuifolius and $R$. acetosella consists of individuals in the generative phase (in the young tree stand $-100 \%$, fallow land $-80 \%$, old tree stand $-78.0 \%$, plantation $62.4 \%$ ). These species are cropped in the largest amounts in the plantation ( $83 \%$ of contacts with these species). In successive years they formed $1.9,3.4$ and $2.6 \%$ of all contacts.

Melampyrum nemorosum is consumed from June to the end of the growing season. Consumption of this species is greatest during the first half of July (about $10 \%$ of the animals' diet). The generative parts form $64.5 \%$ of contacts with this species (old tree stand $-70.0 \%$, plantation - 54.3\%). Roe deer did not consume the generative parts of $M$. nemorosum in the young tree stand and fallow land. The largest number of contacts with this species were recorded in the young tree stand $\left(74^{\%} / 0\right)$ and plantation $\left(24^{\circ} / n\right)$. In successive years $M$. nemorosum formed $0.1,2.2$ and $1.0 \%$ of all contacts.

Achillea millefolium is eaten from June to the end of the growing season, but it is only at the end of August that the amount eaten 
exceeds $2 \%$, being about $7 \%$. $99.5 \%$ of contacts with $A$. millefolium were recorded in the fallow land, where the generative parts were also consumed ( $7.5 \%$ of contacts). In $1976 \mathrm{~A}$. millefolium formed $4.2 \%$ of all contacts, but in the two following years its percentage was negligible.

Fungi appear in the roe deer's diet twice during the year, their peak percentage occurring in September (about 7\% of the animals' diet). In the pre-spring period the percentage formed by this group was about $5 \%$. In spring it was chiefly bracket fungi and other fungi growing on tree trunks, and also Gyromitra esculenta, which were consumed. In autumn the roe deer consumed chiefly pileus-bearing mushrooms of the following species: Boletus edulis, Armillariella mellea, Paxillus involutus, Russula virescens and Amanita citrina. The largest number of contacts with fungi was recorded in the old tree stand $(73 \%)$. In successive years fungi and mushrooms formed $0.1,0.3$ and $0.6 \%$ of all contacts.

Quercus robur was cropped by roe deer throughout the whole year. The percentage of the vegetative parts of this species did not exceed $5 \%$ in their diet. In September roe deer begin to feed intensively on acorns, and as a result in November $Q$. robur forms over $22 \%$ of their diet. In the old tree stand acorns form $35.8 \%$ of all contacts with this species. During the growing season in the plantation and young tree stand roe deer fed chiefly on the browse of $Q$. robur (94.4 and $84.8 \%$ of contacts with this species), but in the old tree stand and fallow land chiefly leaves $(92.5 \%$ and $98.2 \%$ ). Over the whole year in the old tree stand roe deer readily consumed browse and leaves lying on the ground $(68.4 \%$ of contacts in this age class of tree stand with $Q$. robur). In successive years $Q$. robur formed $3.3,1.2$ and $1.4^{0} \%$ of all contacts.

Carpinus betulus forms an important component of the roe deer's diet throughout the year, and particularly in months with persistent snow cover, when it forms almost $75 \%$ of the animals' whole diet. From the end of April to the end of June its percentage does not exceed $11 \%$ and from July to November inclusive $-27 \%$. During the growing season $72 \%$ of contacts with $C$. betulus consisted of its browse (old tree stand $91.9 \%$, young tree stand $-89.5 \%$, plantation $-77.4 \%$, fallow land $7.6 \%$ ). Roe deer sporadically ate the fruit of $C$. betulus. This species is consumed chiefly in the old tree stand $(49 \%$ of contacts with this species). In successive years it formed $16.9,11.2$ and $16.1 \%$ of all contacts.

Oxalis acetosella is a species of which the maximum proportion in roe deer's diet occurs in the late autumn, winter and pre-spring period. In the late autumn it constitutes $49 \%$ of the animals' diet, in winter when there is a thaw and the snow cover melts - almost $80 \%$, and in the pre-spring period about $35 \%$ of the animals' diet. During the 
flowering period (May) it exceeds $20 \%$ of their diet. At this time flowers form about $50 \%$ of contacts with this species in the old tree stand. $O$. acetosella is consumed chiefly in the old tree stand, where $94^{0} \%$ of contacts with this species were recorded. In successive years it formed $14.1,26.2$ and $12.5^{\%} \%$ of all contacts.

Viola sp., Populus tremula, Salix caprea and Salix sp., Rubus sp., Betula verrucosa and Sorbus aucuparia are characterized by the absence of a short-lived distinct peak of their consumption by roe deer.

$V$ iola sp. appears in roe deer's diet together with disappearance of snow cover and as from May, ending in September, it forms from 5 to $13 \%$ of the animals' food. In autumn and during winter thaws this percentage does not exceed $3 \%$. During the flowering period $31.1 \%$ of contacts with Viola sp. consist of individual plants in the generative phase (plantation $-78.3 \%$, young tree stand $-69.8 \%$, old tree stand $13.5 \%$. Viola $\mathrm{sp}$. is chiefly consumed in the old tree stand $(71 \%$ of contacts with this species) and in the plantation $(26 \%)$. In successive years it formed $0.9,7.0$ and $12.8 \%$ of contacts.

Populus tremula forms food for roe deer throughout the year, although its percentage in the animals' diet does not exceed $8 \%$. During the growing season the percentage of browse in contacts with $P$. tremula is $33.3 \%$ (young tree stand -- $100 \%$, old tree stand $-37.4 \%$, plantation $-36.4 \%$, fallow land $-0.5 \%$ ). In the old tree stand, while snow cover persists, $33 \%$ of contacts with $P$. tremula consists of twigs fallen to the ground and dry leaves. In spring the flowerheads of $P$. tremula are sporadically eaten. The greatest number of contacts with this species were recorded in the old tree stand $(43.5 \%)$. In successive years P. tremula formed $3.4,3.1$ and 1.6 of all contacts.

Salix caprea and Salix sp. appear in the roe deer's diet in mid-May and continue to form part of it up to the end of winter. From mid-July to the end of October they form from about 11 to about $26 \%$ of the animals' diet. In other months their percentage does not exceed $6 \%$. During the growing season $33.3 \%$ of contacts with these species consists of browse $(100 \%$, old tree stand; plantation $67 \%$, young tree stand $61.8 \%$, and $2.8 \%$ - fallow land). They were cropped chiefly on fallow land $-94 \%$ of contacts with Salix caprea and sp. In successive years their percentage was $24.0,0.4$ and $0.7 \%$ of all contacts.

Rubus sp. is consumed throughout the year. In April, August and from October to the end of winter its proportion in the roe deer's diet is not great and does not exceed $3 \%$. In other months it forms from about 5 to $16 \%$ of their diet. Flowers and fruits are cropped in small amounts - chiefly in fallow land (5.6\% of contacts with Rubus sp.) and in the young tree stand $(4.1 \%)$. The greatest amounts of Rubus 
sp. are consumed in the plantation ( $87 \%$ of contacts with this species). In successive years it formed $0.7,6.0$ and $10.6 \%$ of all contacts.

Betula verrucosa is a component of the roe deer's diet throughout the year in amounts not exceeding $8 \%$. During the growing season $15 \%$ of contacts with this species consists in browse (old tree stand $-100 \%$, young tree stand $-94.1 \%$, plantation - 36.1\%, fallow land $2.5^{\mathrm{o} / 0}$ ). Roe deer consumed maximum amounts of $B$. verrucosa in fallow land ( $75 \%$ of contacts with this species). In successive years it formed 4.8 , 0.5 and $0.5 \%$ of all contacts.

Sorbus aucuparia is consumed by roe deer throughout the whole year, but does not form more than $8 \%$ of their diet. During the growing season $8.9 \%$ of contacts with this species consists of browse (young tree stand $-22.5^{\circ} \%$, plantation $-8.9^{9} \%$, old tree stand $-9.7^{\%} \%$ ). In fallow land roe deer cropped the leaves only of $S$. aucuparia. Maximum number of contacts with this species were recorded in the old tree stand $\left(60.0^{\mathrm{n} / 0}\right)$. In successive years $S$, aucuparia formed $0.5,2.0$ and $1.3 \%$ of all contacts.

\section{DISCUSSION}

Use has been made in this study of the method consisting in observations of feeding groups of tame roe deer, employing the author's own tested ways of procedure (Kossak, 1981). There is no doubt that one of the main advantages of this method is the opportunity to directly follow the course of the animals' feeding on plants.

Wallmo et al. (1973) tested methods employed to define the food preferences of deer, including the method of recording traces of the animals' feeding in defined plots, and using tame individuals of Odocoileus hemionus as the testing factor. Comparison of the two methods showed that consumption of bushes and herb plants by these animals was under-estimated, and that of grasses - over-estimated. Data from the Białowieża Primeval Forest on consumption of Oxalis acetosella by deer, obtained by recording traces of the animals' feeding, given by Borowski \& Kossak (1975), showing that the proportion of this species in the animals' diet was $0.1 \%$, are strikingly different from the data obtained by observation of tame animals, when this proportion is defined as $20 \%$ of contacts. The phenomenon of under-estimation of the proportion of small herbs in the diet of deer most probably occurs as a general rule, and is caused by the impossibility of descrying traces of the cropped plants. As shown by the author's own observations, roe deer also feed on fallen twigs and leaves. This food is completely overlooked when 
using the method of recording traces of feeding. The same happens in the case of the animals consuming fruits and seeds fallen to the ground, which may periodically form an important component of their diet (Lay, 1965).

In all 156 plant species here recorded as occurring in the study area, jointly for the plantation, young and old tree stands, and 81 species on fallow land overgrown with trees, for which the corresponding figures in the roe deer's diet were respectively $96(61 \%)$ and $70\left(86^{0} / 0\right)$. It is justifiable to conclude that a certain number of species were not recorded, this applying to plants growing in small numbers and rarely cropped by roe deer. Their role would, however, appear to be sufficiently small for them to have no significant effect on the results as a whole, apart from extending the list of species. Klotzli (1965) is of the same opinion, putting the degree of consumption of forest plants by roe deer at $75 \%$ and considering a further $5 \%$ as "uncertain", that is, plants which might theoretically be consumed by roe deer. Briedermann (1974) who recorded 400 plant species in the roe deer's diet, also states that the majority of them "are not of importance" and Juon (1963) recorded 100 species in the roe deer's diet out of 160 species growing in Switzerland, i.e. $63^{\%} \%$.

The fact itself of the occurrence of a given plant species in the area does not determine the extent to which the animals feed on it. It may be concluded that of two plant species equally attractive as food, the greater proportion in the animals' diet will be formed by the species which occurs more abundantly in the area. On the other hand, of two similarly abundant plant species in the area, the more attractive species will be more intensively cropped, and thus by comparing supply and demand it is possible to determine the roe deer's food preferences.

When determining the roe deer's food preferences other authors have grouped plants differently. The method closest in its intentions to the one used in this study is the division used by Klötzli (1965). This author divided plants into four groups (from never to intensively consumed), taking as a guide the percentage of phytosociological groups in which traces of cropping the given plant were recorded and the degree of intensity of such cropping.

As can be seen from the data given in section 3, the largest amount of contacts (75 to $91^{0 / n}$ ) by roe deer do not excessively exploit plants. Species occurring very abundantly (from 69 to $86 \%$ of contacts) predominate in contacts. The principle is that if there is intensive consumption of a given species in the given age of tree stand (in relation to abundance of occurrence), then in another class it is less intensively cropped. An exception to this is Populus tremula, which was preferred 
in all age classes of tree stand and in the fallow land. The role of Salix caprea and Salix sp. in the roe deer's food is also interesting. Growing numerously in the fallow land, it forms as much as $29 \%$ of contacts and in the young tree stand, where it is scanty, it is greatly preferred. The role of Salix in the diet of deer has been emphasized by other authors (cf. e.g. Klötzli, 1965), but even so cases are still encountered of removal of Salix caprea and other willows from young tree stand and forest plantations during cultivation operations as "annoying weeds", and some textbooks even recommend this (Ilmurzyński, 1969).

No case was noted in the present studies of a plant not occurring abundantly, but belonging to preferred species, forming a considerable proportion in the sum total of contacts. The absence of the phenomenon of "searching for" plants can be partly explained by the observations of the roe deer's feeding behaviour, namely no feeding roe deer were observed to move in a definite direction of a "selected" plant or group of plants. Feeding consists in the animals moving in zigzags and choice takes place in the immediate vicinity of its muzzle. Thus the chance of the animal coming on a plant is determined, in addition to its numbers in the area, presumably also by its localization - plants growing near the regular paths of roe deer in the young tree stand, through the plantation to the old tree stand, were more intensively cropped than in other places in the enclosure.

The foregoing does not provide confirmation of the opinions held by other researchers (Szmidt, 1975; Szukiel, 1972, 1979) that roe deer particularly readily feed on rare and sporadically occurring plants. It may be that the situation is different in areas with little variety of plant species, since roe deer, on account of the poor choice of plants suitable for their food, are obliged to search for such plants.

It must be clearly emphasized that the moderate use made by roe deer of plants applies only to situations when the head of animals is small enough for it not to exceed the food resources of the habitat.

In studies on the food of deer, its variations over the annual cycle must not be overlooked, and thus the majority of papers on this subject take this aspect into consideration. The division of the year most commonly used is into seasons (Dzięciolowski, 1967; 1970; Sidua et al., 1969 ; Kohn \& Mooty, 1971 ; Morow, 1976), or months (Severcov \& Sablina, 1953 ; Sablina, 1955; Borowski \& Kossak, 1972, 1975). Both these divisions are open to some objection. Considering animals' food in 4 or 5 seasons is suitable for preliminary definition of the proportion of different groups of plants, but is insufficient for a description of the course taken by the animals' feeding on different species. In this case division into months is slightly better, but may also be a source of error, namely 
if a plant is intensively cropped at the turning point between two months the phenomenon may not be perceived. Consequently in the present study the year has been divided into 19 feeding periods containing different numbers of days, taking rapidity of changes in vegetation and in the animals' diet as a guide. The start of the annual cycle was taken as April 1st, since in the Bialowieża Primeval Forest the snow cover usually disappears just about this date (Aulak, 1976). During the period from 1st April to 1st August feeding periods are short, consisting of 10 days each. This is connected with the development of the herb layer, in which greater changes take place during spring and early summer, in respect of quantitative dynamics, biomass dynamics, production etc. Aulak, 1976) and in consequence also in the roe deer's diet. The correctness of using these short feeding periods in spring and early summer is shown by the example of the roe deer's diet in April and May (Section 4). In April ligneous plants jointly form $14 \%$ of the animals ${ }^{*}$ diet and in May $9 \%$, that is, slightly less. If, however, the roe deer's food during these two months is considered in six 10-day periods a new phenomenon in revealed: during April there is a marked decrease in their feeding on ligneous plants (from $33 \%$ during the first to only $2^{0} \%$ during the third 10-day period). This low percentage of ligneous species in the roe deer's diet continues through two 10-day periods of May (respectively 6 and $7 \%$ ), after which it rises to as much as $23 \%$ in the third 10-day period. In the light of the foregoing it may be said that in the biotope of the mixed deciduous tree stand in the Bialowieza Primeval Forest the period of the lowest proportion of ligneous plants in the roe deer's food occurs on the days between 10th April and 20th May, and is caused by the appearance of herbs in the herb layer.

A second, but less distinct, decrease in intensity of browsing on ligneous plants occurs in late autumn. It may be concluded that the reason for this is the fact that browse is not very attractive, since it is leafless at that time, whereas certain herbs (e.g. Oxalis acetosella) still form very nutritive food (Drożdż, 1979).

The third decrease during the annual cycle of the proportion of ligneous food, occurring during winter thaws, resulting in disappearance of snow, which enables the roe deer to feed abundantly on Oxalis acetosella - confirms the hypothesis as to the low degree of attractiveness of browse. The following conclusion may therefore be drawn: NonIigneous plants form particularly attractive food to roe deer, that is, herb plants and the voung non-ligneous shoots of ligneous plants and their leaves. The high percentage of woody shoots in the roe deer's food during the time the snow cover persists is to a great extent compulsory, owing to the limited access to the herb Iayer. This is confirmation of 
what has been postulated for a long time - the necessity of clearing snow from the herb layer in order to enable deer to feed on food remaining green in winter.

A similar opinion on the role of ligneous plants in the roe deer's food has been expressed by Hofmann (1978), who stated that in spring, summer and autumn roe deer consume food rich in nutrient elements and poor in cellulose, that is, leaves, stems and flowers. Fibrous food, such as ligneous twigs or blades of grass, is unsuitable as the roe deer's stomach has too few bacteria breaking down cellulose and such plant material, not fully utilized, leaves the stomach. In another paper (Hoffmann \& Geiger, 1974) the authors quite simply consider the roe deer the opposite of red deer, which they term "a twig and branch cropper". Ellenberg (1975) has expressed a similar opinion in saying that the roe deer chooses, wherever possible, easily digested and high energy food.

The nearest area in which the roe deer's food was studied is the Soviet part of the Białowieża Primeval Forest. Severcov \& Sablina (1953) and Sablina (1955) studied the roe deer's food over the yearly cycle. These authors decidedly consider as opposites the herb part and ligneous part of these animals' diet, terming these two "kinds" of food their antipodes. This type of reasoning in relation to food relations would appear to be completely incorrect, namely, assuming that the roe deer must consume over a 24-hour period a given amount of food (Bubenik, 1959 : about $2.5 \mathrm{~kg}$; Briedermann, 1974 : from 1.5 to $2.5 \mathrm{~kg}$ ) it is obvious that when there is a lack of herb plants the animal is obliged to consume greater amounts of ligneous plants. The above authors also state that the roe deer is less fastidious in its feeding than the red deer, and consequently the number of species forming its food is small, i.e. 43 species. This is directly contrary to the results of studies by other authors (Klötzli, 1965; Fanta, 1974; Hofmann \& Geiger, 1974 ; Bruchholtz, 1975 ; Hofmann, 1978, 1979). who agree in emphasizing the exacting demands of the roe deer in respect of composition and variety of its diet. Szczerbinski (1967) states that in respect of its food the roe deer is more fastidious than red or fallow deer. Severcov \& Sablina (1953) and Sablina (1955) state that from October to March inclusive the roe deer does not feed on herb plants at all. Jurgenson (1968), on the other hand states that in autumn roe deer consume 13 herb species (6-70\% of their food) and in winter 3-4 species (2--5\% of their food). The results obtained in the present study clearly show that it is only the snow cover which eliminates herbs from the roe deer's diet.

The relation shown in section 3 (Supply and demand for plants) between the proportion of the roe deer's diet formed by a species and the abundance of the latter in the area has been defined, treating both 
diet and abundance of plants statically, that is, omitting seasonal variations and differences in successive study years. Meanwhile the variable quantitative and qualitative composition of their diet over the yearly cycle depends on the growing cycle and consequently also on their abundance.

From 1971 to 1974 studies were carried out in the Białowieża Primeval Forest on the development and production of the herb layer in a TilioCarpinetum Tracz. 1962 association (Aulak, 1976). The numbers of individual plants of different species varied during the growing season. A general rule is that the density of plants (abundance) increases from spring to the peak time after which, as the result of elimination after the period of maximum density, it decreases. Species developing and dying early (i.e., Anemone nemorosa, Dentaria bulbifera) exhibit zero density during the late summer and autumn. These species have a typical distribution of density ( $\min -\max -\mathrm{min}$ ). In the case of species persisting throughout almost the entire growing season, there are certain divergences from a typical distribution of density, namely on the curve of their numbers, on some of the parts, after a periodical decline, a second peak occurs in their course. The system is thus the min-max-min-maxmin type. The reason for this is the appearance of new individual plants. In the case of some species, (e.g. Stellaria holostea, Stellaria nemorum, Galeobdolon luteum and Aegopodium podagraria) new individual plants appear through the greater part of the growing season, even fairly abundantly towards the end of summer, that is, during the period when growth is gradually ceasing. In addition it has been found that with a suitable amount of rainfall, Galeobdolon luteum and Stellaria nemorum, for instance, not only produce throughout the whole period of spring and summer, but that summer production is often greater that than in spring (Aulak, 1976).

Analysis of the dynamics of quantitatives states is incomplete if we fail to take elimination into consideration. Population numbers form the resultant of the production of new individuals and elimination of old ones. Elimination of individual plants begins in principle from the start of the appearance of a population, but it varies in intensity over the growing season. For instance, in the case of Stellaria holostea, Stellaria nemorum, Hepatica nobilis and Galeobdolon luteum, it is fairly evenly distributed, the maximum occurring towards the end of the time for which the population of these species persists. In the case of Aegopodium podagraria and Asperula odorata two peaks of elimination may occur; the first in June, the second in summer (with Asperiula odorata) or autumn (with Aegopodium podagraria).

The relative stability of population density is not necessarily evidence 
of the absence of rotation, neither is reduction in quantity synonymous with absence of production. Tumidajowicz (1973) found that young individual plants form a considerable proportion of herb layer biomass in late autumn, the majority of their production taking place during the following year.

The density of different species varies not only seasonally, but also in successive years. Differences apply not only to the maximum number of individuals and the course in time of the density curve, but also in the average length of life of individuals and their average weight. In two successive years of study on Oxalis acetosella, in one year there was only one peak of abundance on August 1st, but in the second year the curve had three culminations, the greatest occurring on 10th July. Part of the population survived the winter, in 1973 a far greater number of individual plants entering the over-wintering period than in the preceding year. The combined amount of production of all species taken into consideration in the studies occurred in three successive years in ratios of $1.00: 2.16: 2.36$. Aulak (1976) considers that the cause of the above lies in differences in the distribution of certain environment parameters (e.g. amount of precipitation).

In the light of the foregoing findings as to development and production dynamics of the herb layer, an attempt may be made at interpreting one of the causes of the annual distribution observed of consumption by roe deer of different species of plants (section 4.4). Species characterized by a short growing period and one peak of abundance occur for a short time only in the animals' diet, and their maximum proportion occurs during the flowering period (Anemone nemorosa). Species with a longer growing and production period occur in the roe deer's diet throughout the whole growing season and are characterized by several percentage maxima (grasses and sedges, Fragaria vesca, Viola sp., Rubus sp.). Species of which part of the population survives the winter are consumed in late autumn, during winter thaws and the pre-spring period by roe deer in large amounts (Oxalis acetosella, Vaccinium myrtillus, Fragaria vesca, grasses and sedges). Annual species, growing in spring and dying after producing seeds, form a far greater proportion of the animals' diet in early summer (Melampyrum nemorosum).

The differences observed in the percentage of contacts in 1977 and 1978 may have been due on the one hand to the succession taking place in the wooded clearing the year before the studies began (Fragaria vesca - increase in percentage from 4.2 to $7.9^{\%} \%$, Rubus sp. from 6.0 to $10.6 \%$, Viola sp. from 7.0 to $12.8 \%$ ) and on the other hand may be connected with variations in production in successive years. This applies chiefly to species occurring abundantly and consumed in the old tree 
stand, only slightly subject to succession (e.g. Oxalis acetosella decrease in percentage in successive years from 26.2 to $12.5 \%$ ).

The above remarks indicate how necessary it is to approach these problems more thoroughly than has been the case up to the present, as connected with definition of food resources calculated from the biomass of plants available to the animals. This biomass varies in quality in seasons, biotopes and years, and in the case of different species of plants.

In Halls' opinion (1970), the composition of the animals' diet is determined by what are known as the animal's food requirements, consumption of the minimum amount of food components being a basic condition for optimum functioning of the organism. A measure of the nutritive value of food is its digestbility and chemical composition (Barnes, 1965). These two parameters have a decisive influence on the animals' food preferences in relation to different plants and their parts.

In order to live the roe deer requires food, at least $58 \%$ of which can be digested (Drożdż, 1979), but the digestibility of plants varies very greatly over the course of the year. It is greatest in spring (this applying to both ligneous and herb plants) and decreases with the passage of time. Only certain herb plants retain their digestibility on a high level throughout the whole growing season (Oxalis acetosella and Mycelis muralis). Very generally speaking, plants are highly digestible in spring and summer, and have a low degree of digestibility in autumn and winter.

As digestibility of ligneous plants does not exceed $35 \%$ in autumn and winter, roe deer may suffer from digestible energy starvation. In Halls' opinion (1970) this type of starvation is the most common deficiency in the diet of ruminants. The most important task facing the animals during this time is to obtain food of maximum digestibility. The results obtained in the present study revealed a transitional decrease lasting up until the first snowfalls, in the roe deer's feeding on ligneous plants during the late autumn period, at which time consumption of Oxalis acetosella markedly increased. As shown by Drożdż (1979), digestibility of ligneous plants abruptly decreases after the leaves fall. It may therefore be concluded that roe deer feeding on herb plants supplement insufficiency of digestible energy. This is also shown by the fact that roe deer feed on $O$. acetosella during periods of winter thaw. Unfortunately no data have been encountered in literature on the digestibility of herb plants during the winter. During both the present studies, and studies made by other authors (Crawford, 1969; Lösekrug, 1978) roe deer were found readily to feed on fallen dry leaves of trees and bushes of many species. Although their digestibility is similar to that of browse 
(about 39\%/1) nevertheless, as Drożdż (1979) states, they are rapidly digested and therefore quickly pass through the alimentary tract, which is also one of the ways in which roe deer satisfies its energy requirements during winter.

The food situation of roe deer in spring and summer is completely different. Plants contain the maximum amount of nutritive substances and are most digestible for roe deer during the period of their growth, that is, in spring and summer. During this time the digestibility of browse is about $64 \%$ and in the case of herb plants even exceeds $80^{\circ} \%$ (Drożdz, 1979). This value is thus far higher than that required by these animals, and it must therefore be concluded that during this time digestibility plays a subordinate role in the animals' choice of diet. That this is so can be concluded from reports made by different authors explaining the reasons for the roe deer's preference for given plants or parts of plants. This was most decidedly stated by Humphrey (1962), who concluded that "preference is not in conformity with nutritive value". Crawford (1969) states that if part of a plant is intensively cropped but poorly digested, it cannot be considered as a valuable component of the animals' diet, unless it supplies a basic dietetic element required by the animals in small quantities. Researchers often record cases of deer feeding on plants with negligible nutritive value, but characterized by a considerable amount of smell and taste substances (Esser, 1958; Bubenik, 1959). There are thus grounds for concluding that it is also active bodies, i.e. organic compounds with high biological activity, which cause the animals to consume such plants. These substances (tannins, alkaloids, glycosides, etheric oils, gentians, resins, organic acids, carotins and vitamins) on the one hand increase the taste value of food (Rice \& Church, 1974), and on the other constitute an important addition in the animals' diet, acting on the animals ${ }^{*}$ organism in a specific way: nutritive, prophylactic, curative or poisonous (Polakowska, 1977).

A large number of cases have been found in this study of particularly intensive feeding by roe deer on plants during the period of their flowering or fruiting. During the spring-summer season the generative parts of plants form about $33^{\text {n }} / 0$ of the animals' diet. It has also been shown that roe deer prefer flowering plants from among the infertile individuals of Anemone nemorosa and Oxalis acetosella (Section 4).

Apart from the high concentration of active bodies, during the flowering period the plant is most digestible and contains the highest concentration of nutritive substances. It should not therefore be concluded that it is solely the level of active bodies which determine the roe deer's preference for plants during the generative phase. Nevertheless, 
in spring roe deer have at their disposal a large number of herb and ligneous plants both highly digestible and nutritive, even though not passing through generative phases. It may therefore be assumed that the high concentration of given specific active substances contained in flowers and fruits is the chief (although not the only) reason for the occurrence of the preference described.

A tendency which predominates in studies on the food of deer is to search for one constant factor (reasons for preferring a plant) which is to determine the extent to which the animals make use of the plant. Authors consider this to be either digestibility or the contents of given plants. Approaching the problem in this way leads to contradictory results and consequent to the discussion so often encountered in literature. The food consumed by the animal is in fact the result of what the biotope has to offer and what the animal requires. Both biotope and animal are highly variable. The number of individual plants and species of available plants vary, the plant itself is also variable, and the animals' requirements vary. What is constant is the condition that the organism must obtain suitable food within a suitable time. It is to comply with the above condition that the food preferences of the animals vary. The term itself "food preference" is apt to be used in too wide a sense. It must be emphasized that the roe deer does not prefer plants as food. They are animals, as herbivores, adapted to feeding on them. 'They therefore consume plants, chiefly those which they find in sufficient quantities. Preferences only appear when composing thei diet as a whole from the plant elements available, and determine which of them, in which quantities and at what time, they are included in its composition, and in effect form a picture of food relations.

The organism conveys the message of its requirements physiologically and by means of the senses, and the animal in feeding satisfies them. In winter there may be a lack of digestible protein, causing a state of starvation, and in spring there may be an excess of protein causing disturbances in digestion. In both cases a different type of preference serves to satisfy requirements. In winter this will be a preference for food easily and quickly digested, and in spring a preference for food containing tannins and ballast substances. The existence of one, and one only, constant in time, "reason for preference" would lead to disaster for the organism.

Consideration as a whole of the trophic situation of roe deer led to the following conclusion: The picture of the food relations of roe deer is the resultant maintained in a state of dynamic equilibrium, of habitat abiotic and biotic elements variable in time and space, and of the equally variable requirements of these animals. The sole function of food pre- 
ferences is to maintain this dynamic equilibrium. The factor determining the shaping of food relations always consists in the currently prevailing food resources.

\section{REFERENCES}

1. Aulak W., 1976: Rozwój i produkcja runa w zespole Tilio-Carpinetum Tracz. 1962 jako jednego z elementów podstawowego poziomu troficznego $w$ ekosystemach leśnych. Zesz. Nauk. SGGW AR w Warszawie. Rozprawy Naukowe, $60: 1-151$.

2. Barnes R.F., 1965: Use of in vitro rumen fermentation technique for estimating forage digestibility and intake. Agron. J., 57: 213-216.

3. Borowski S. \& Kossak S., 1972 : The natural food preferences of the European bison in seasons free of snow cover. Acta theriol., 17 : 151-169.

4. Borowski S. \& Kossak S., 1975: The food habits of deer in the Bialowieża Primeval Forest. Acta theriol., $20: 463-506$.

5. Briedermann L, 1974 : Was äst unser Rehwild? Unsere Jagd,, 24 : 110-111.

6. Bruchholz S., 1975: "Bohnenkaffe" fürs Rehwild. Unsere Jagd, 25 : 198-199.

7. Bubenik A., 1959: Grundlagen der Wildernährüng. Deutscher Bauernverlag: 1-299. Berlin.

8. Crawford H.S., 1969: Evaluating food use - new methods and techniques. White-tajled deer in the southern forest habitat. Proc. Symp. at Nacogdoches, Texas, March 25-26, 1969 : 109-114.

9. Drescher-Kaden U. \& Seifelnasr E. A., 1977 : Untersuchungen am Verdauungstrakt von Reh, Damhirsch und Muflon. Mitteilung 3: Mikroorganismen im Pansen von Reh, Damhirsch und Muflon. Z. Jagdwiss., 23: 64-69.

10. Drożdż A., 1979: Seasonal intake and digestibility of naturat foods by roedeer. Acta theriol, $24: 137-170$.

11. Dzięciolowski $R$., 1967: Food of the red deer in a annual cycle. Acta theriol., $12: 503-520$.

12. Dzięciolowski R, 1970 : Foods of the red deer as determined by rumen content analyses. Acta theriol., $15: 89-110$.

13. Ellenberg H., 1975 : Neue Ergebnisse der Reh-Okologie : Zählbarkeit, Wachstum, Vermehrung. Allg. Forstzeitschr., 30: 1113-1118.

14. Esser W., 195B : Beitrag zur Untersuchung der Äsung des Rehwildes. Z. Jagd-wiss., $4: 1-40$.

15. Faliński J.B. (ed.), 1968: Park Narodowy w Puszczy Bialowieskiej. Państw. Wyd. Roln. i Leśne : 1-503. Warszawa.

16. Fanta B., 1974 : Novè metody při sledovàni vyhledảvanosti jednotlivých druhư dřevin zvěr̆i. Lecnictvi, 20: 1069-1093.

17. Halls L. K., 1970 : Nutrient requirements of livestock and game. Range and wildlife habitat evaluation. A. Research Symposium USDA, Forest Service Misc. Publ, $1147: 10-18$.

18. Hofmann R. R. \& Geiger G., 1974: Zur topographischen und funktionellen Anatomie der Viscera abdominis des Rehes (Capreolus capreolus L.). Anat. Histol. Embryol., 3: 63-84.

19. Hofmann R. R., 1978: Die Stellung der europäischen Wildwiederkäuer im System der Äsungstypen. [In: Hofmann R. R., Ed. "Wildbiologische Informationen für den Jäger"]. Jagd + Hege Verlag, I: 9-18. St. Gallen. 
20. Hofmann R. R., 1979: Die Ernährung des Rehwildes im Jahresablauf nach dem Modell Weichselboden. [In: Hofmann R, R, Ed. "Wildbiologische Informationen für den Jäger"J. Jagd + Hege Verlag, 2 : 12l-136. St. Gallen.

21. Humphrey R. R., 1962 : Range ecology. Ronald Press Co. : 1-234. New York.

22. Ilmurzyniski E, 1969 : Szczególowa hodowla lasu. Państw. Wyd. Roln. 1 Leśne: 1-703. Warszawa.

23. Juon P., 1963: Uber neuere Erkenntnisse zur Frage der Rehwildernährung. Schweiz. Ztschr. Forstwesen, 114: 98-117.

24. Jurgenson P. B, 1968: Ohotniči zvieri i ptici (prikladnaja ekologija). Izd. Lesnaja Promyšlennost' : 1-30. Moskwa.

25. Klötzli F., 1965: Qualität und Quantität der Rehäsung in Wald- und GrunlandGesellschaften des nördijchen Schweizer Mittellandes. Veröff. Geobot. Inst. ETH, Zürich, $38: 1-186$.

26 Kohn B.E. \& Mooty J.J., 1971: Summer habitat of white tailed deer in north-central Minnesota. J. Wild. Manage, 35: 476-487.

27. Kossak S., 1981: Hand-rearing and care of a group of roe-deer. Acta theriol, $26: 207-218$.

48. Kossak S., 1982 : Zimowe dokarmianie saren. Prace Inst. Bad. Leśn. in print.

29. Kossak S. \& Myśliński S., : Cykl roczny aktywnosici saren. In prep.

30. Kurt F., 1968: Zusammenhänge zwischen Verhalten und Fortpflanzungsleistung beim Reh (Capreolus capreolus L.). Z. Jagdwiss., 14 : 97-106.

31. Lay D.W, 1965: Fruit utilization by deer in southern forestes. J. Wildl. Manage., $29: 370-375$.

32. Lösekrug G:R., 1978: Naturverjüngung und Reh-Asung. Allg. Forstzeitschr,, $33: 334-335$.

33. Morow K., 1976 : Food habits of moose from Augustow forest. Acta theriol, $21: 101-116$.

34. Polakowska M., 1977 : Leśne rosliny zielarskie. Paŕstw. Wyd, Roln. i Leśne : 1-266. Warszawa.

35. Pawłowski B., 1972: Skład i budowa zbiorowisk roślinnych oraz metody ich badania. [In1: "Szata roślinna Polski", Eds Szafer W., \& Zarzycki K.]. Państw. Wyd. Nauk. : 237-269. Warszawa.

36. Rice P.R. \& Church D.C., 1974: Taste responses of deer to browse extracts, organic acios and odors. J. Wildl. Manage., $38: 830-836$.

37. Sablina T. B., 1955: Kopytnye Belovežskoj Pušci. Trudy Inst. Morf. Zivotnyh im. A. Severcova, $15: 90-114$.

38. Severcov A.S. \& Sablina T.B., 1953: Olen', kosula i kaban v zapovednike "Belovežskaja Pǔ̌̌a". Inst. Morf. Żivotnyh im. A. Severcova, 9: 180-184.

39. Siuda A., Zurowski W. \& Siuda H., 1969: The food of roe deer. Acta theriol, $14: 247-262$.

40. Szczerbiński W., 1967: Zagadnienie sarny (Capreolus capreolus). [In: Szczerbinski W. Ed., „Kilka zagadnień nowoczesnego lowiectwa"]. Skrypty WSR: 25--84. Poznań.

41. Szmidt A., 1975: Food preference of roe deer in relation to principal species of forest trees and shrubs. Acta theriol., $20: 255-266$.

42. Szukiel E., 1972 : Spałowanie drzew przez zwierzynę jako problem ekologiczny. Wiad. ekol., 18 : $339-359$.

43. Szukiel E., 1979: Szkody $w$ lasach Polski na tle zagęszczenia jeleniowatych. Prace Inst. Bad. Leśn., 546 ; 135-155. 
44. Tumidajowicz D., 1973: The dynamics of biomass and primary production of herb layer plant in the deciduous Tilio-Carpinetum association of the Niepolomice Forest. Bull. Acad. pol. Sci., Cl. II, 21 : 101-107.

45. Van de Veen H. E., 1979: Food selection and habitat use in the red deer (Cervus elaphus L.). Rijksuniversiteit te Groningen : 1-263.

46. Wallmo O.C., Gill R. B., Carpenter L. H. \& Reichert D. W., 1973 : Accuracy of field estimates of deer food habits. J. Wildl. Manage, $37: 556-562$.

47. Zasady hodowlane, 1969: Wyd. 3. Państw. Wyd. Roln. i Leśne: 1-410. Warszawa.

Accepted, September 24, 1982.

\section{Simona KOSSAK}

\section{SYTUACJA TROFICZNA SAREN W LESIE MIESZANYM SWIEZYM}

\section{Streszczenie}

Badania prowadzono na terenie polskiej części Puszczy Białowieskiej w latach 1976- 79 metodz obserwacji żerowania 7 oswojonych saren obu plci. Badaniami objęto dwa tereny grodzone: 1) 0,82 ha (ugór + mlodnik), 2) 21,34 ha lasu mieszanego swieżego (uprawa + młodnik + starodrzew). Wykonano inwentaryzacje botanjczna terenow zagrodzonych. Skład pokarmu określono $w$ oparciu o kontakty. Za 1 kontakt uznano jednorazowe zgryzienie i przełknięcie przez sarnę fragmentu, calej lub kilku egzemplarzy danej rośliny. W oparciu o zanotowane kontakty i obfitosć poszczególnych gatunków roślin prześledzono stosunki podaży i popytu $w$ lesie mieszanym swiezym. Ilosciowy i jakościowy skład diety saren $w$ cyklu rocznym określono przy pomocy zunifikowanych pod względem wagowym jednostek zerowania tzw. kęsow.

Całośt danych (121.706 kontaktów) zebrano w listę florystyczna (Tabela 2). Stopień korzystania przez sarny $\mathrm{z}$ dostępnego im żeru określono w oparciu o porownanie wartości wspólczynnika obfitości rosliny i jej udziale w kontaktach pobranych $w$ danej klasie wieku drzewostanu (Tabela 4). Eącznie na badanym terenie stwierdzono występowanie 155 gatunków roślin, $z$ czego $w$ pokarmie saren znalazło się 97. Gatunki występujace licznie lub masowo w przeważnej części wchodzà do diety saren (Tabela 5). Większośc gatunków z którymi w danej klasie wieku nie zanotowano kontaktów, maja niski wspólezynnik obfitości. Wśród roślin występujących licznie a nie jedzonych $w$ danej klasie wieku drzewostanu, przeważaja te, $z$ ktorymi na calym badanym terenie nie notowano kontaktów. Charakterystyczne dla stosunków pokarmowych saren $w$ lesie mieszanym świeżym jest, iż popyt określony jest przez podaż (70-90\% kontaktów dotyczyło grupy roslin zgryzanych proporcjonalnie do wysteppowania). Gatunki o których można sadzic, że popyt na nie jest wyższy od podaży stanowia $8-24 \%$ kontaktow.

Cykl roczny żerowania saren rozpatrzono w 19 okresach żerowych (Tabela 7). 
Rośliny drzewiaste mają najniżsy udzjal w diecie saren wczesna wiosna, latem stanowia ponad jej polowę a zima, przy zalegającej pokrywie śnieżnej - prawie 100\% (Ryc. 1). Zimowe odwilże połaczone ze znikaniem sniegu wywoluja drastyczfly spadek zerowania saren na roslinach drzewiastych na korzyść roslin zielnych. Rosiliny zielne dominuja $w$ pokarmie saren od konca kwietnia do połowy lipca, $w$ późniejszych okresach ich udział maleje, by po pojawieniu się stalej pokrywy śnieżnej stanowić jego znikoma część. Trawy i turzyce oraz grzyby zjadane są glównie wiosna i jesienia.

Omówiono skład ilościowy i jakościowy diety saren w cyklu rocznym. Przedstawiono przebieg i charakterystykę żerowania saren na wybranych gatunkach rostlin. 